Issues That Impact Oregon Adults Age 45 and Older, December 2020 


\section{TABLE OF CONTENTS}

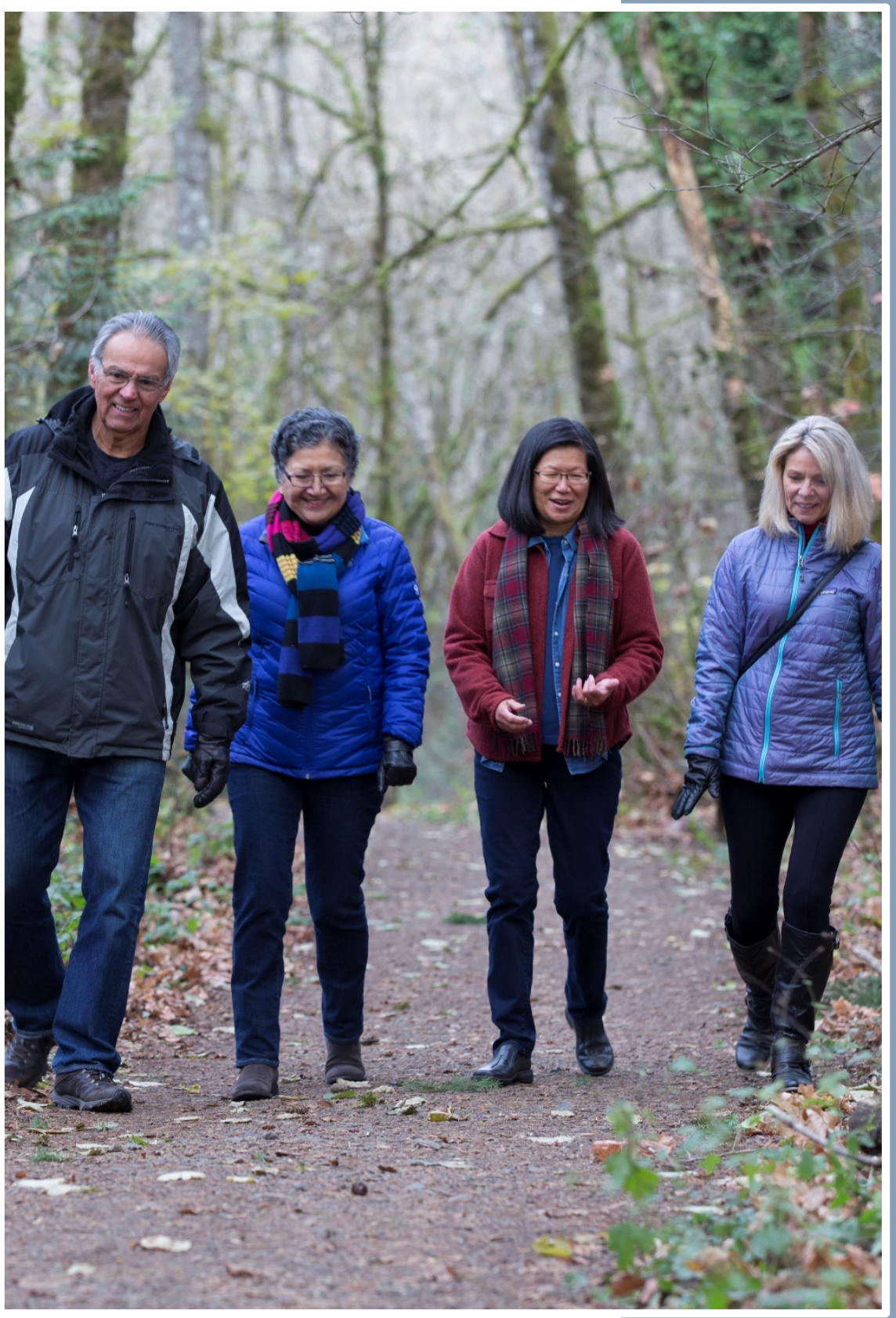




\section{INTRODUCTION}

There are currently about 117 million Americans who are 50 and older; this number will grow to 157 million by 2050. The 50 and older population is and will continue to be an essential contributor to American society. Understanding the needs and opinions of older Americans is critical to ensuring they live longer and healthier lives.

Vital Voices is a new and exciting program of research undertaken by AARP. Through this research program, we are launching a new initiative that will deliver critical, current, and state-specific data to 53 states on a rolling three-year schedule between 2019 and 2021. We are making this data available to the public to assist with the development of programs, products, and policies for older adults. This data will allow those in leadership positions to:

- Predict the need for a specific program or interest in a particular issue.

- Enhance program and product innovation and development.

- Track issues and attitudes over time to assess shifts in public opinion.

- Take action on critical advocacy issues.

Never before has AARP launched a research program of this size and with this much promise. We give it to you, hoping that it will significantly impact the work you do.

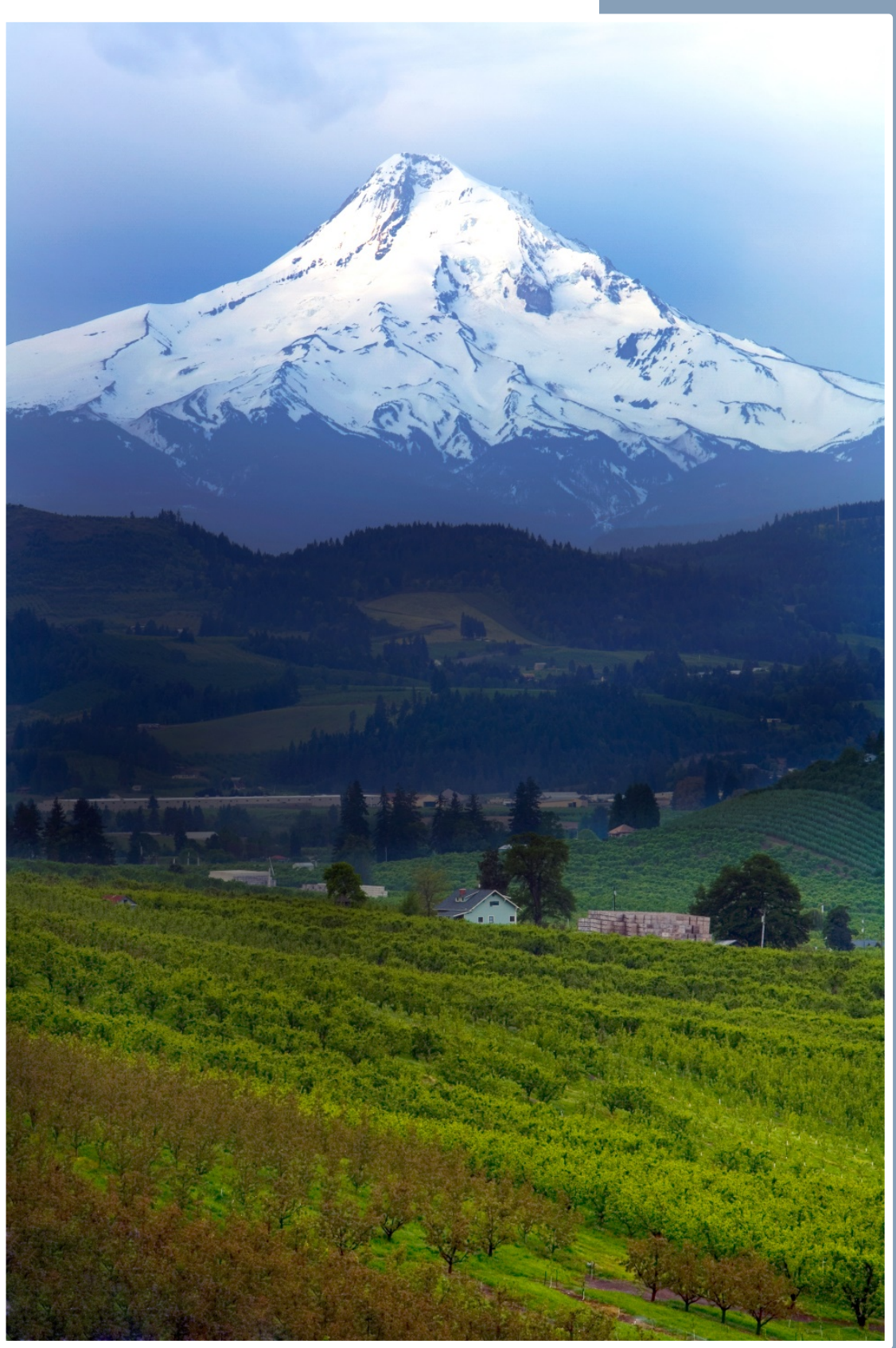




\section{Survey Results}

for OregonHealth Questions

Issues That Impact Oregon Adults Age 45 and Older
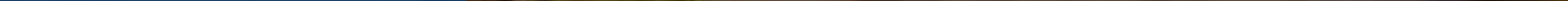


\section{ISSUES OF IMPORTANCE}

Oregon residents age 45+ think many healthcare issues are important, with staying mentally sharp and physically healthy topping the list.

\section{Important Healthcare Issues}




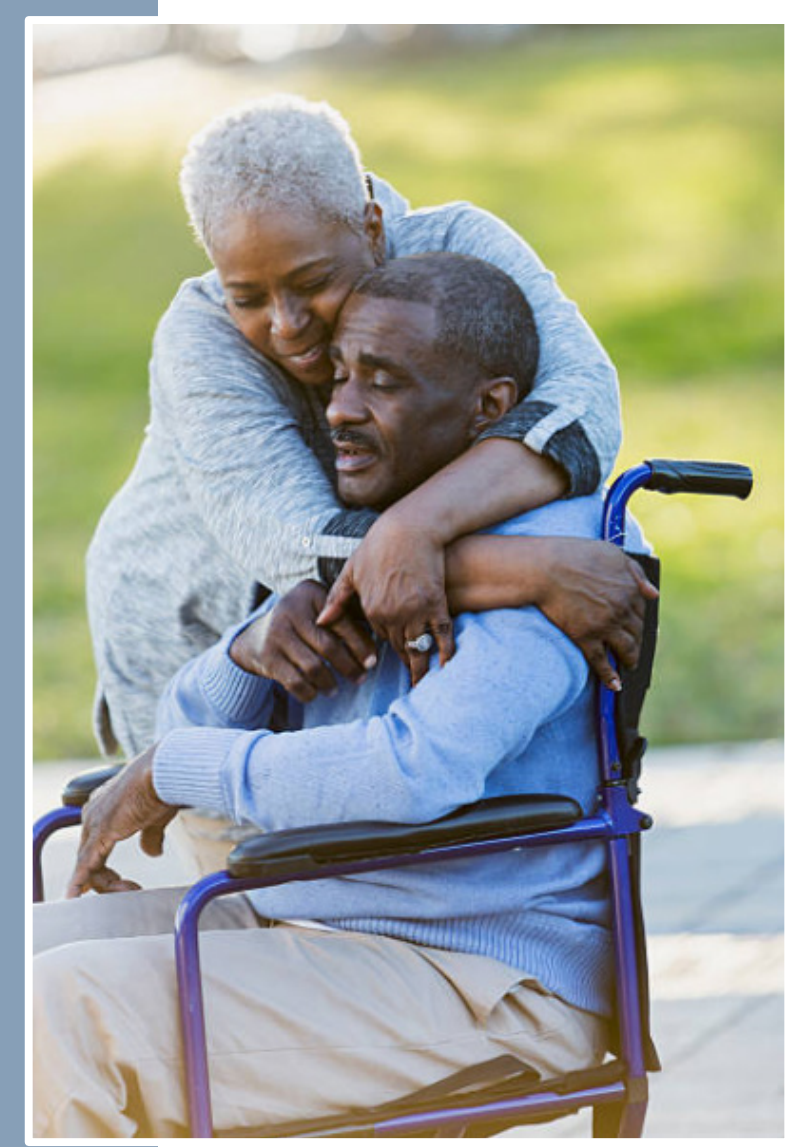

CARE1. Are you currently providing unpaid help to a relative or friend 18 years or older to help them take care of themselves? $(n=709)$

\section{CAREGIVING ISSUES}

Nearly one-third (31\%) of Oregon residents age 45+ are currently providing unpaid help to an adult relative or friend.
Percent Providing Unpaid Adult Care

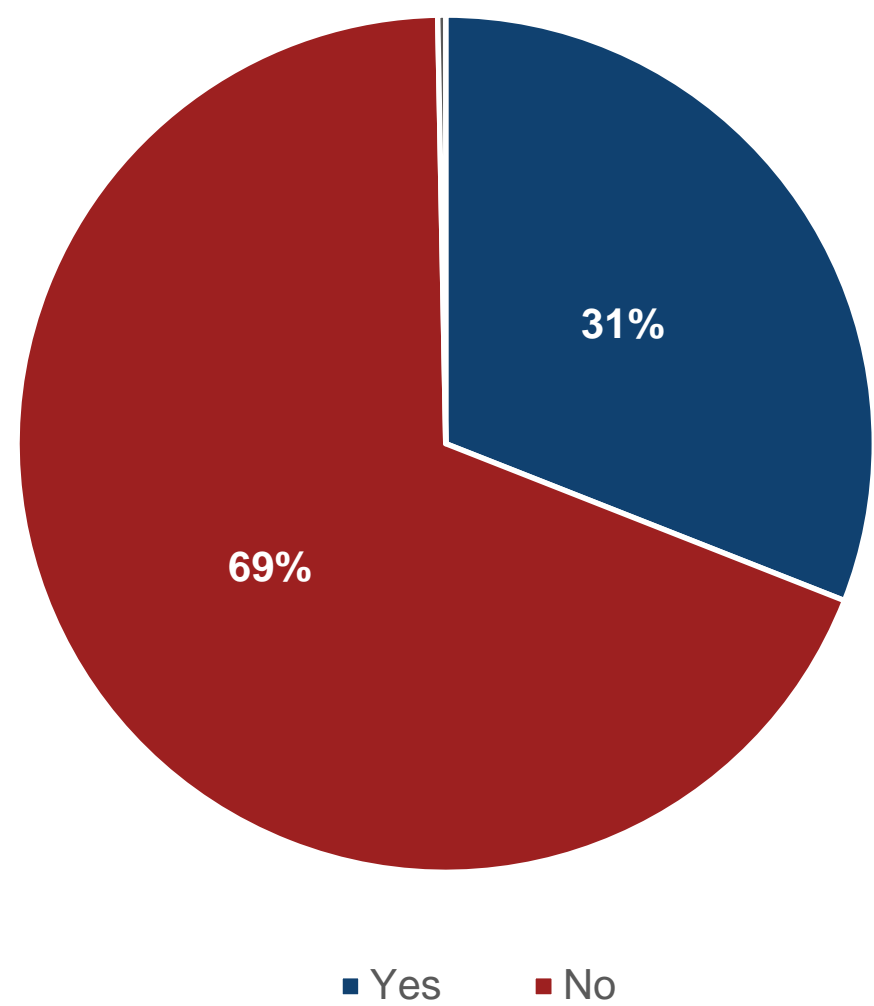




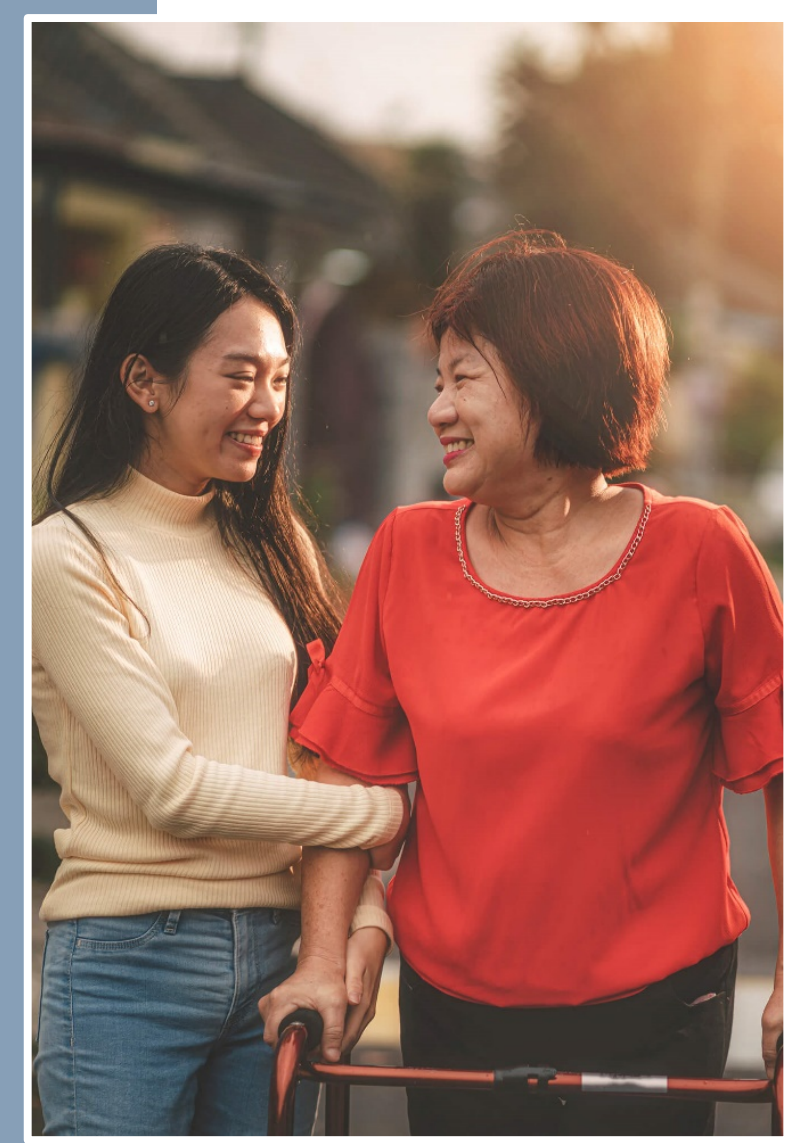

CARE1_A. Have you ever provided this type of unpaid help in the past? $(\mathrm{n}=489)$

\section{CAREGIVING ISSUES}

More than half (54\%) of Oregon residents age $45+$ who are not currently unpaid caregivers have provided this type of care in the past.

\section{Percent Providing Unpaid Adult Care in The Past}

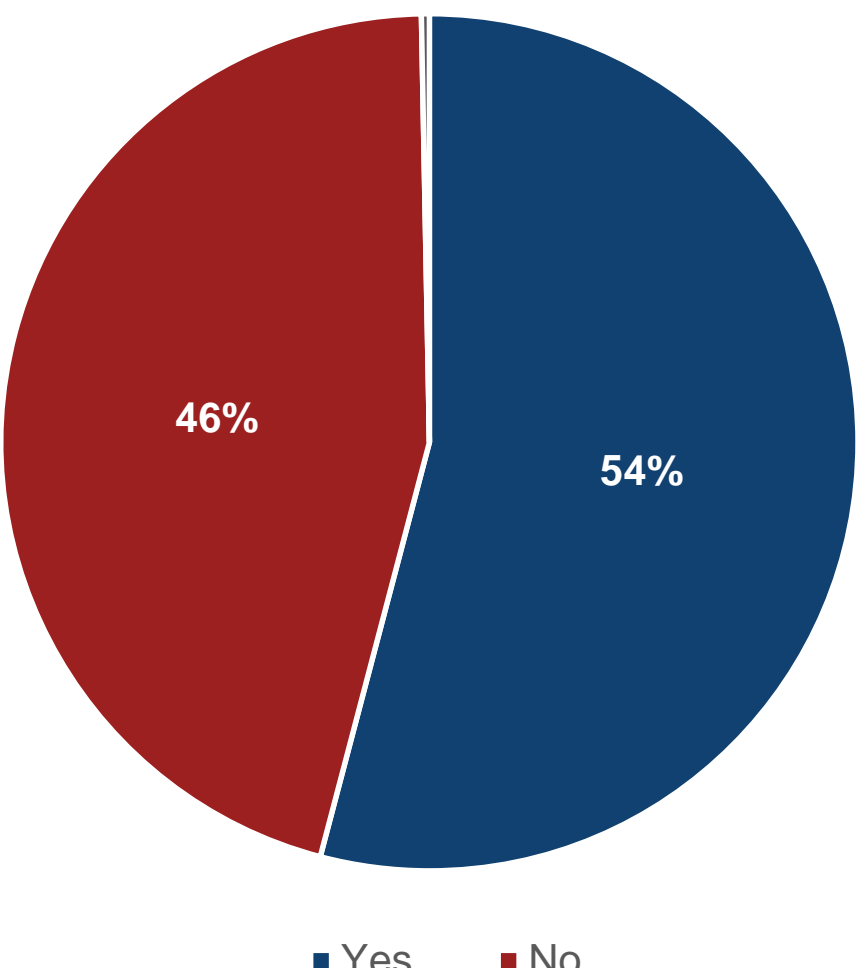




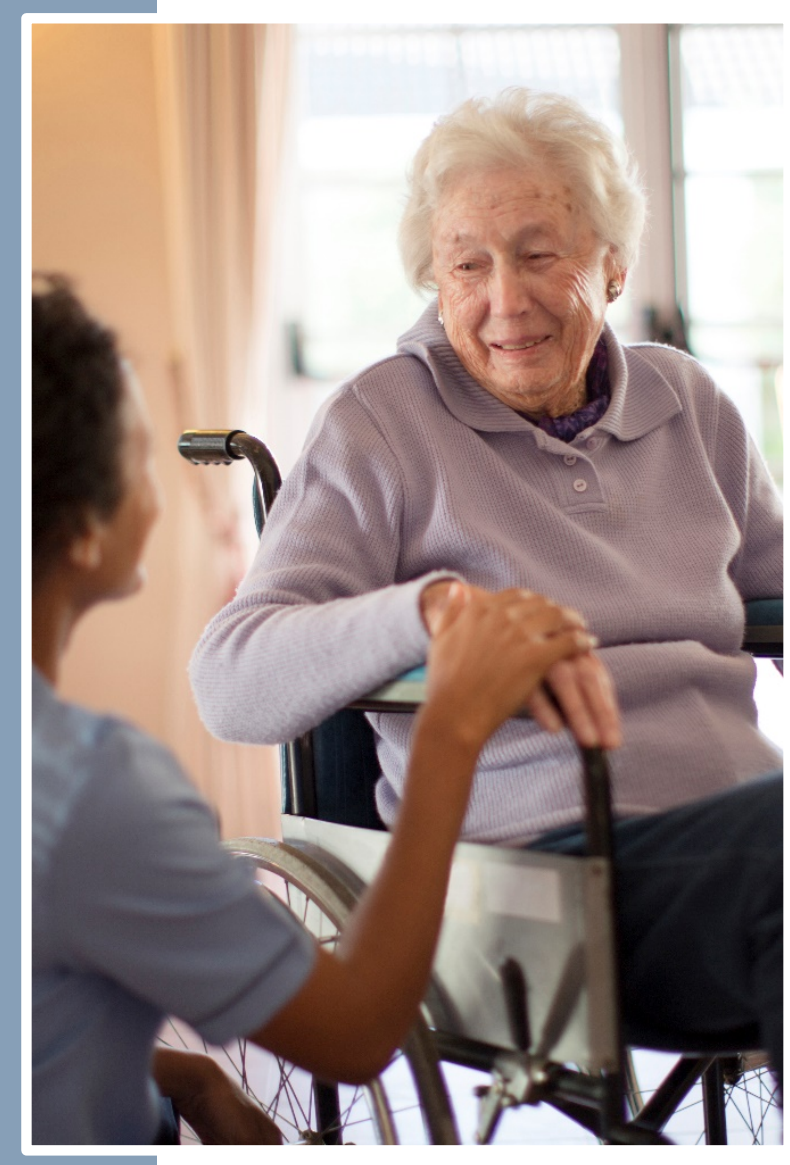

RESP4. If a loved one you care for/cared for needed more help than you could provide today, would you choose...? $(n=484)$

\section{CAREGIVING ISSUES}

Nearly two-thirds (65\%) of Oregon caregivers age $45+$ would choose in-home care with professional help for their loved one if it was needed.

Preference Regarding Care for a Loved One

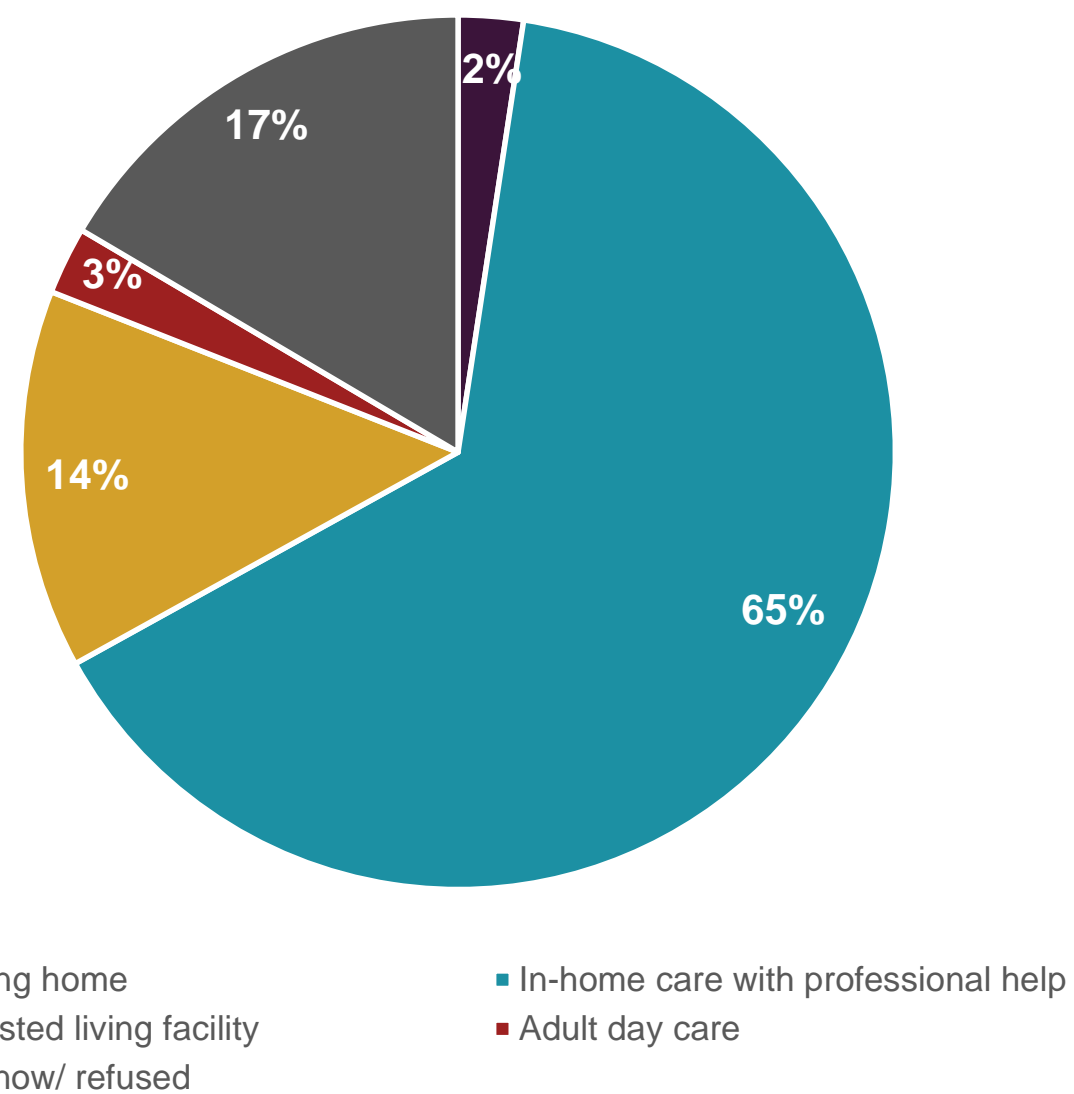




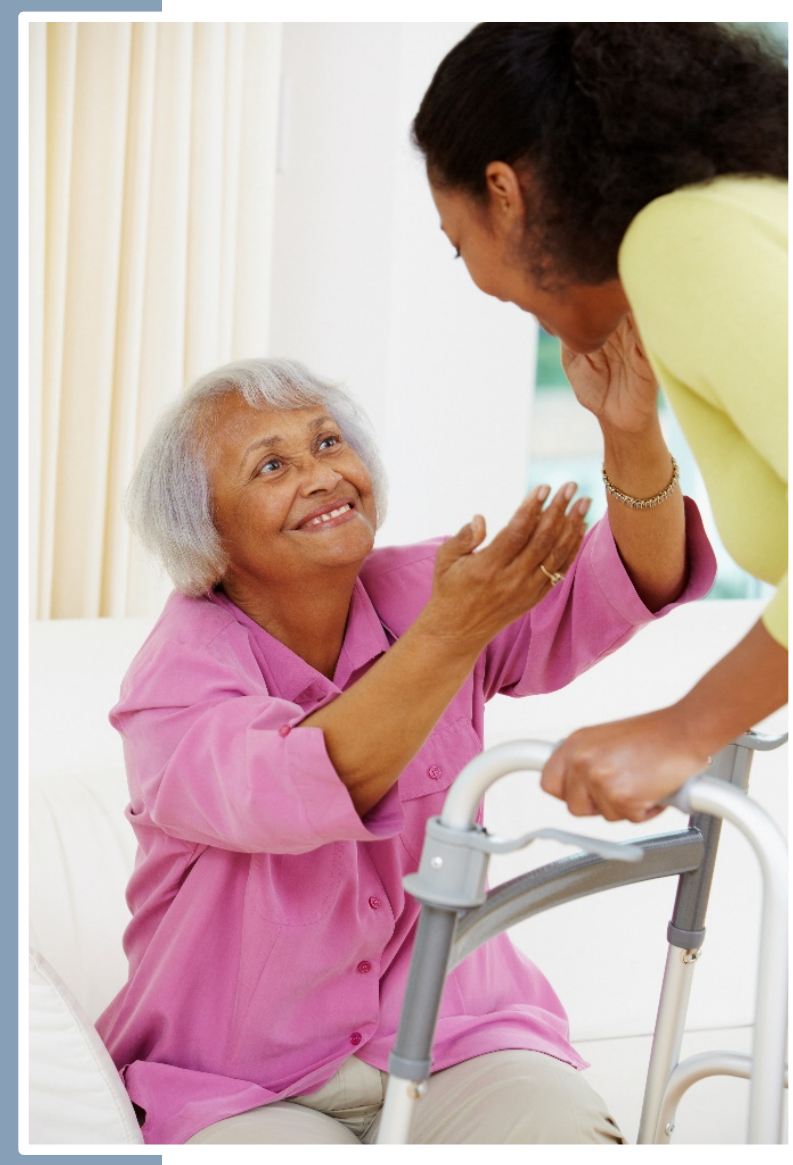

RESP1. What types of respite care do you think are available in your area? $(\mathrm{n}=219)$

\section{CAREGIVING ISSUES}

One-third (34\%) of current Oregon caregivers age 45+ don't know what types of respite care services are available in their area.

Available Respite Care

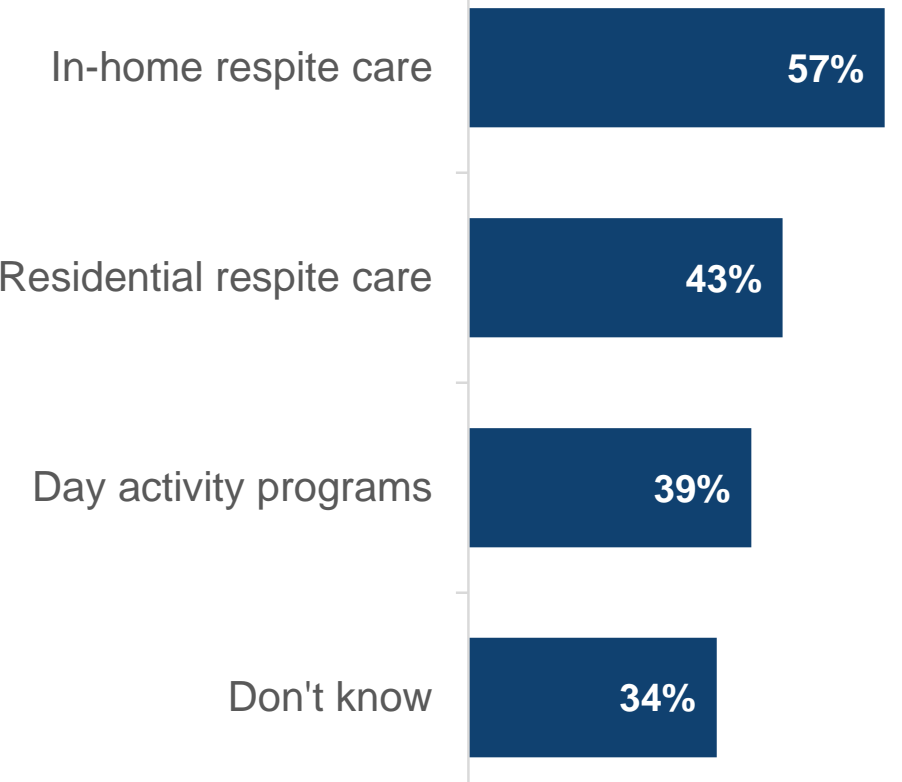




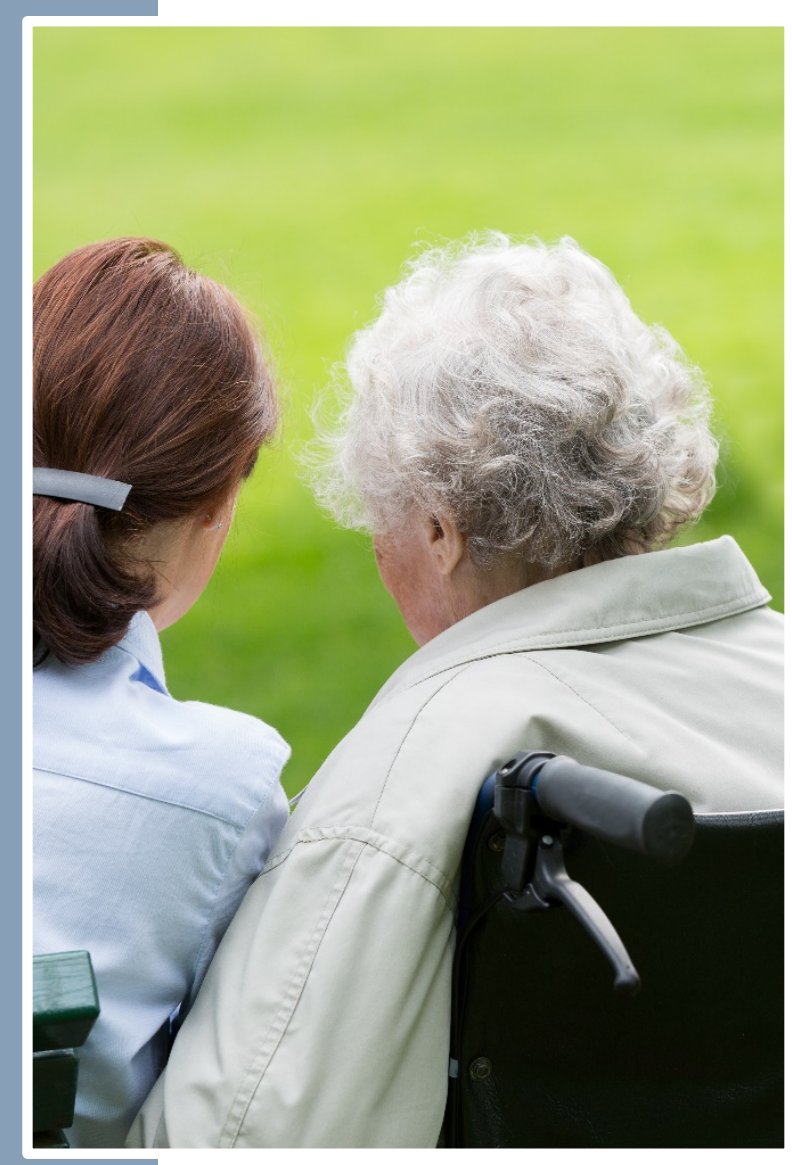

RESP3. Do you support or oppose expanding funding for respite care to family caregivers who provide care and support a family member living in Oregon? $(n=484)$

\section{CAREGIVING ISSUES}

A large majority (86\%) of current or former Oregon caregivers age 45+ would strongly support or somewhat support expanding funding for respite care for family caregivers.

\section{Support for Expanding Funding for Respite Care for Family Caregivers}

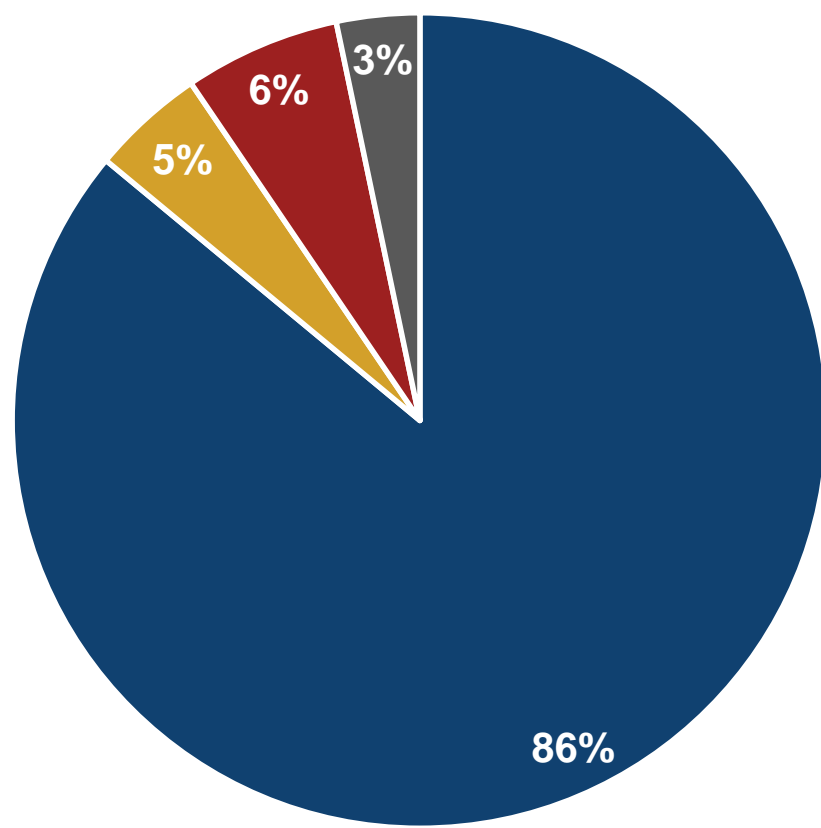

- Strongly support/ somewhat support

- Somewhat oppose/ strongly oppose

- Neither support nor oppose - Don't know/ refused 


\title{
HEALTHCARE
}

\section{In the past year, two in ten (20\%) Oregon residents age $45+$ decided not to go to a doctor or specialist when needed because of the cost.}

\section{Actions Taken in the Past 12 Months Regarding Healthcare}

\author{
Decided not to go to a doctor or specialist when needed \\ because of the cost \\ Gone to the emergency room instead of your primary physician \\ Delayed getting a prescription filled because of the cost \\ Taken less medicine than prescribed to make it last longer \\ Decided not to fill a prescription because of the cost \\ Cut back on items such as food, fuel, or electricity to afford \\ prescription drugs \\ Ordered your prescription drugs by mail or Internet from another \\ country because they cost less \\ Traveled to Canada or another country to purchase prescription \\ drugs because they cost less
}

$18 \%$

\section{$10 \%$}




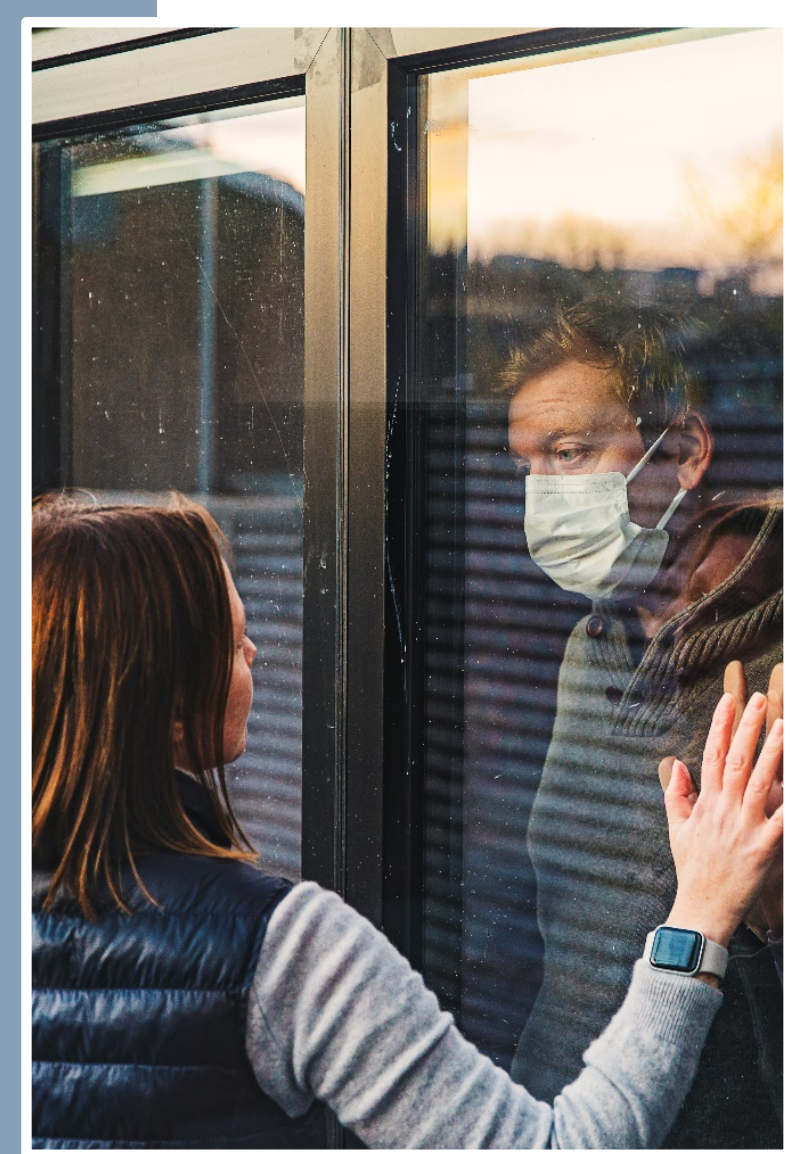

CVD-6. How worried are you about getting coronavirus in the next year? $(n=709)$
COVID-19

Oregon residents age 45+ have mixed levels of concern about getting coronavirus in the next year.

Worry About Getting COVID-19 in the Next Year (as of November/December 2020)

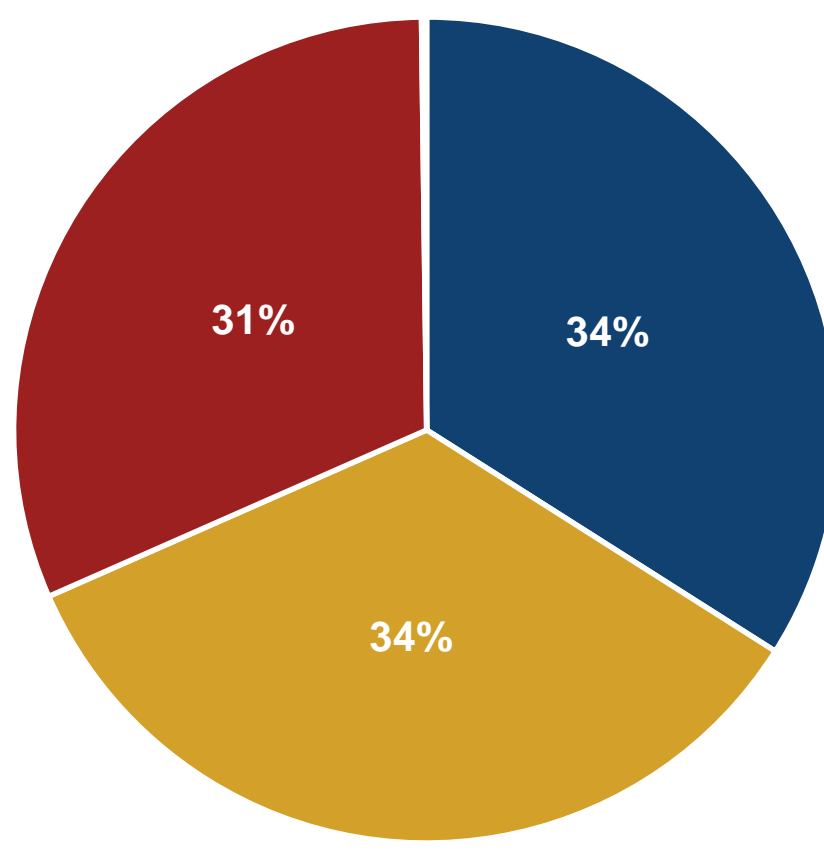

- Extremely worried/ very worried

- Not very worried/ not at all worried

- Somewhat worried

- Don't know/ refused 


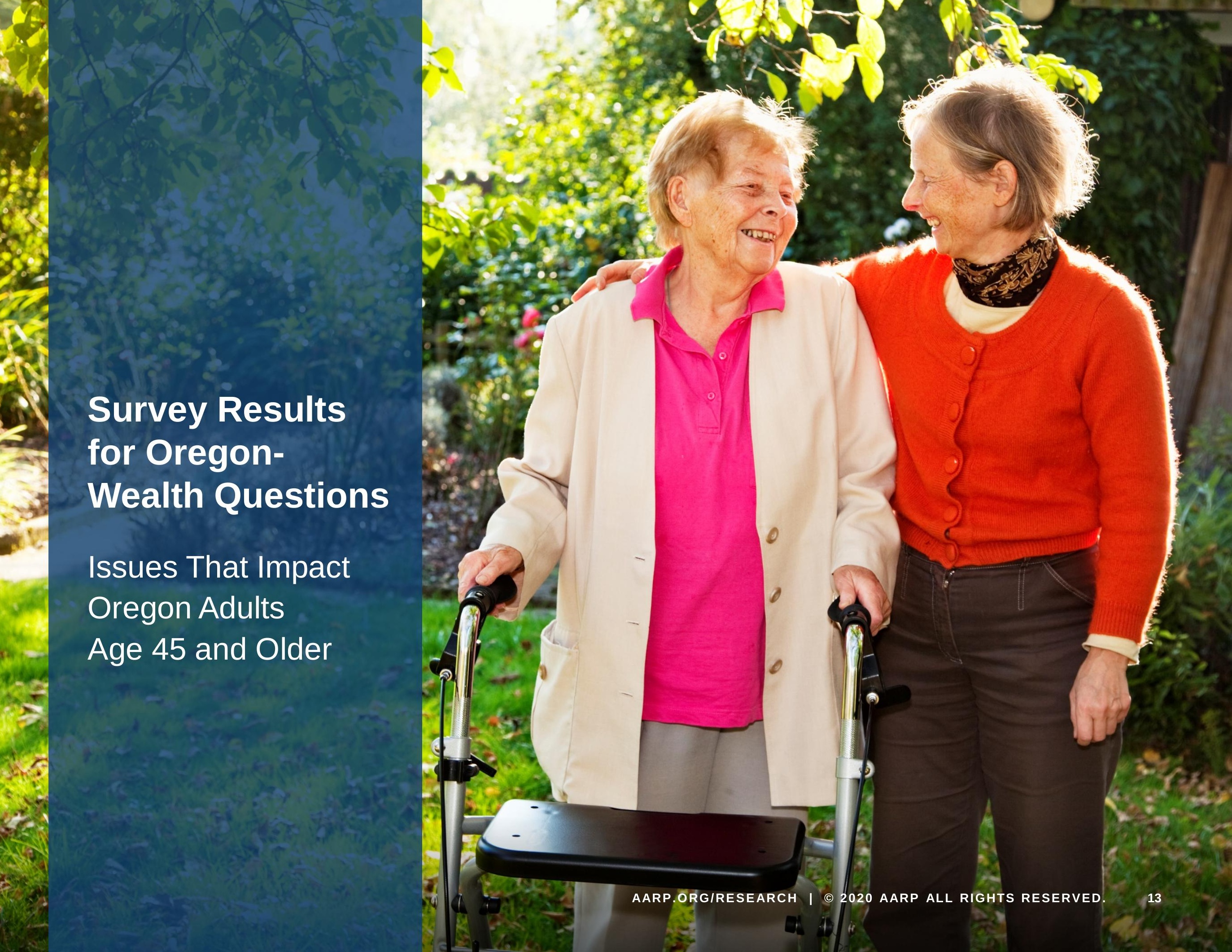




\section{ISSUES OF IMPORTANCE}

\section{Oregon residents age 45+ find many economic issues important, particularly those related to financial security and retirement.}

\section{Important Economic Issues}

Having financial security throughout your life

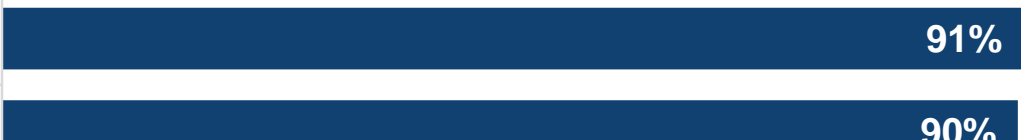

Having enough income or savings to retire

Having adequate Social Security benefits

Protection against consumer fraud

Protection against unfair financial practices

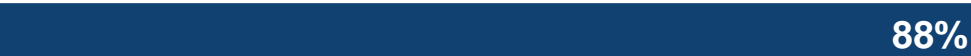

Having online security

Being able to stop working for pay at the age you want Having good employment opportunities in your community

Protection from age discrimination

Having access to high-speed Internet

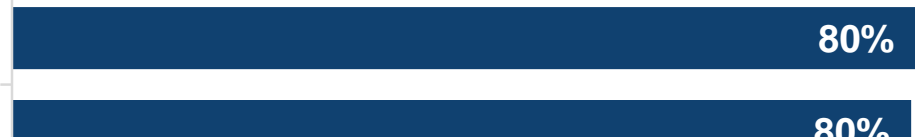

$71 \%$
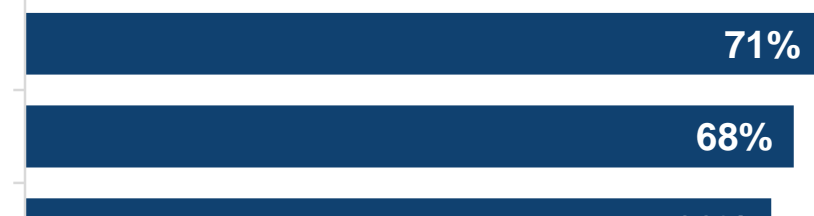

$66 \%$

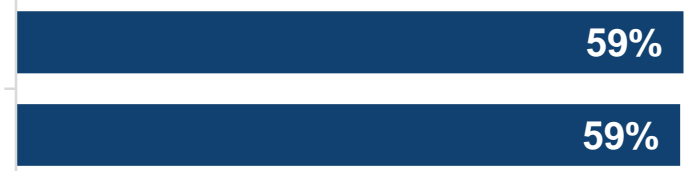

Maintaining relevant job skills and experience

$52 \%$

11. For the following list of issues, please indicate how important each is to you personally. (Percent 'extremely important' or 'very important') (n=709) 


\section{RETIREMENT ISSUES}

Over half (56\%) of Oregon workers age $45+$ are extremely concerned or very concerned about having enough income or savings to retire.

\section{Concerns About Retirement Plans}
Having enough income or savings to retire $(n=453)$
Ensuring the solvency and security of your retirement plans $(n=709)$

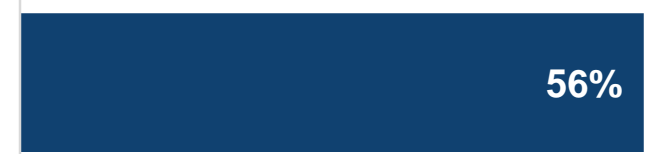

Having to postpone retirement $(n=453)$ 


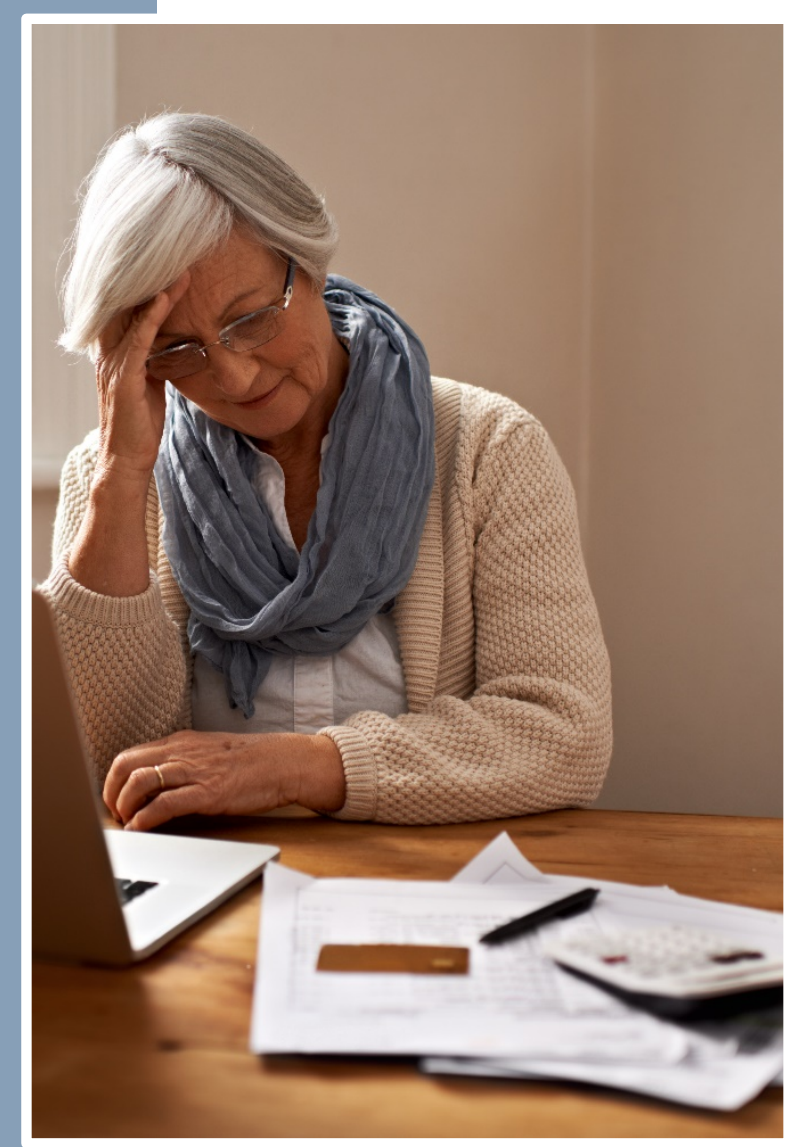

RET23. Has the COVID

pandemic caused you to make

any changes to your retirement

plans, like...? ( $\mathrm{n}=709)$

\section{RETIREMENT ISSUES}

As of Novemberl December 2020, six in ten (61\%) of Oregon residents age 45+ have canceled travel plans because of the COVID pandemic.

\section{Changes to Plans Since the COVID Pandemic}

Canceled travel plans

Tapped into savings or a 401(k) in 2020

Put off buying or selling your home

None of these
Stopped contributions to investments

Delayed retirement

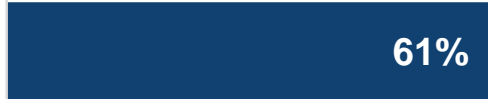

$20 \%$

$16 \%$
$8 \%$ 


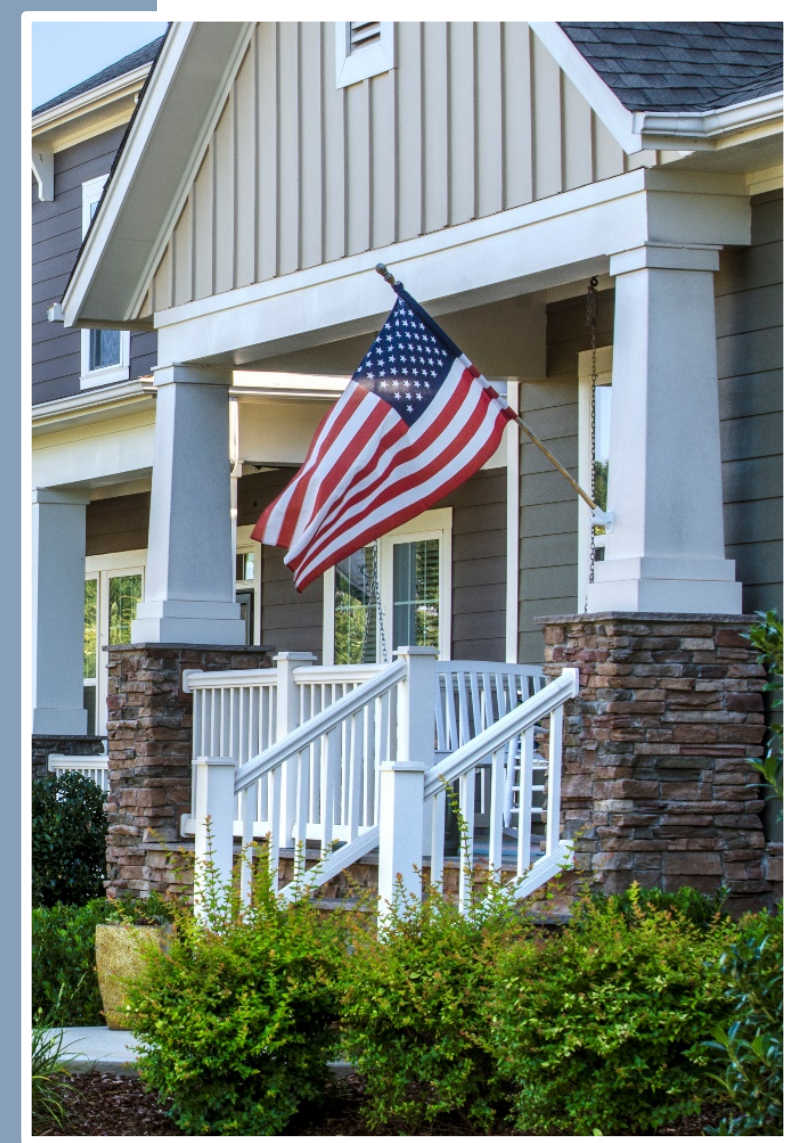

HOU1. Do you think housing affordability is a problem in the area where you live? $(\mathrm{n}=709)$

\section{HOUSING}

More than three-quarters (79\%) of Oregon residents age $45+$ think that housing affordability is a problem in the area where they live.

\section{Housing Affordability a Problem in the Area}

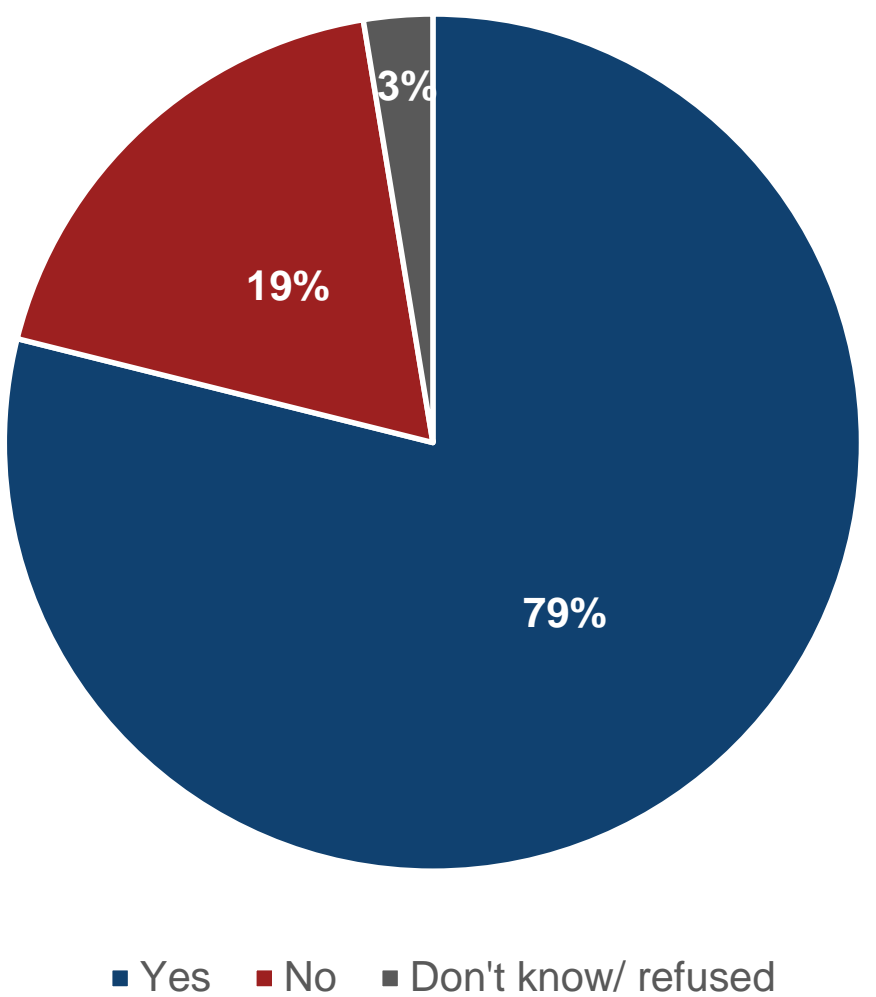




\section{HOUSING}

Among Oregon residents age 45+ who think housing affordability is a problem in their area, six in ten (62\%) reported that the problem is very serious.

The Issue of Housing Affordability

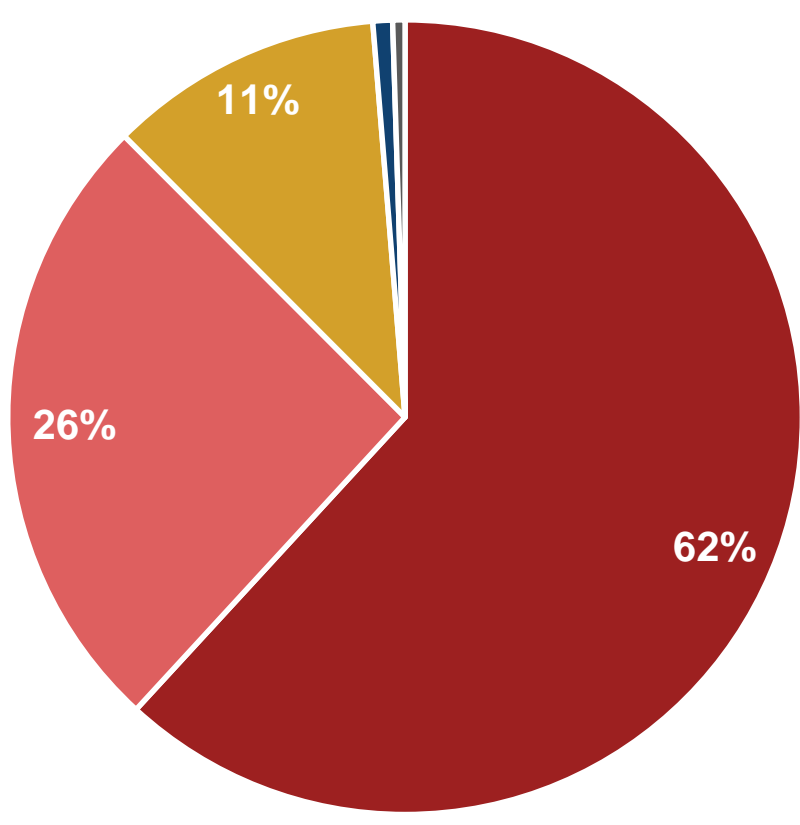

\footnotetext{
- A very serious problem

- Just somewhat of a problem

- Don't know/ refused
}

- A fairly serious problem

HOU1_A. Do you think housing affordability is a very serious problem, a fairly serious problem, just somewhat of a problem, or just a minor problem in the area where you live? ( $n=559)$ 


\section{HOUSING}

More than three-quarters (78\%) of Oregon residents age $45+$ would strongly or somewhat favor allowing developers to build more housing units if they are affordable to families.

\section{Housing Affordability Issues}

Allowing developers to build more housing units if they are affordable to families

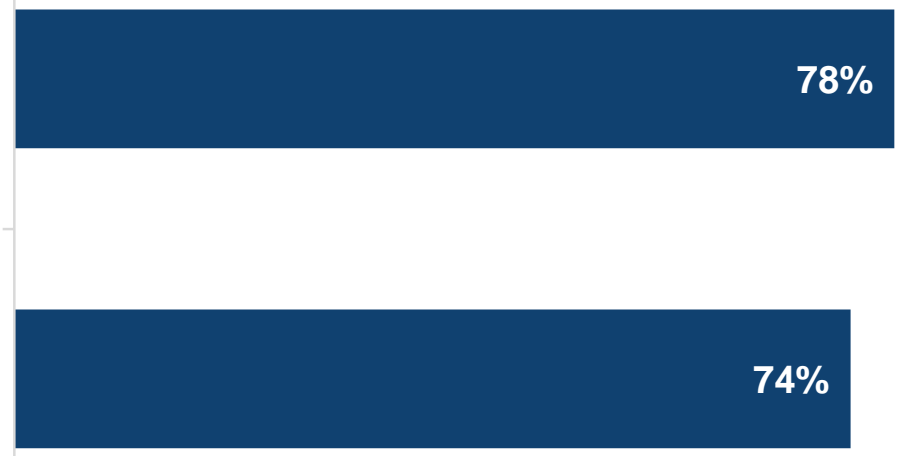

Expanding rental assistance to ensure that the approximately 292,800 Oregon renters who currently qualify for rental assistance but are not receiving it, get it

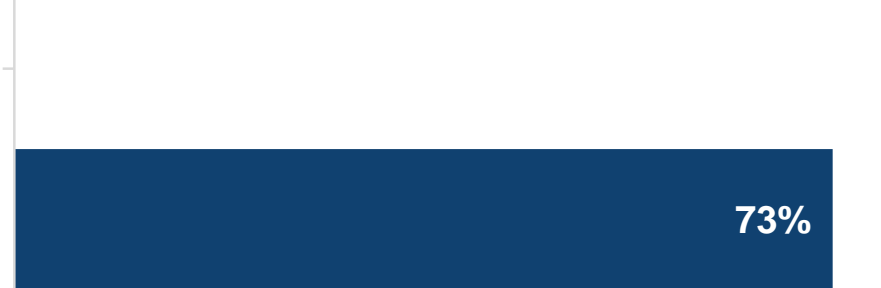

Requiring that at least $20 \%$ of housing in local communities is affordable for families making less than $\$ 47,785$ per year

HOU2. The following are some approaches local, state, or federal government could take to address the problems of housing affordability. Do you favor or oppose...? (Percent 'strongly favor' or 'somewhat favor') (n=709) 


\section{Survey Results}

for OregonSelf Questions

Issues That Impact Oregon Adults Age 45 and Older

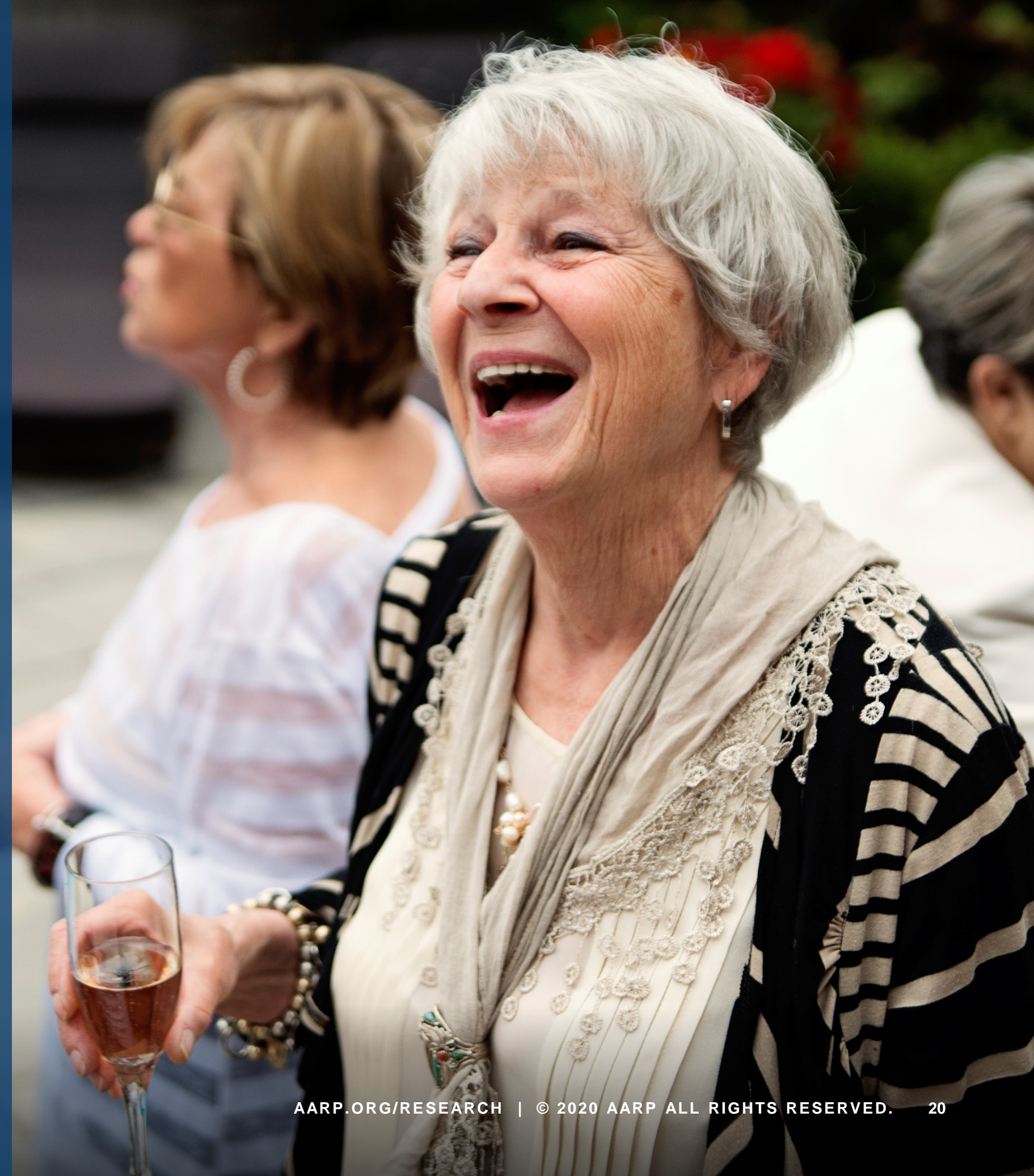




\section{ISSUES OF IMPORTANCE}

Caring for a loved one is extremely important or very important to a majority (85\%) of Oregon residents age $45+$.

\section{Important Independent Living Issues}

Caring for a loved one

Getting to the places you need to go independently

Staying in your own home as you get older

Having alternatives to nursing home care 


\section{ISSUES OF IMPORTANCE}

Safe streets are extremely important or very important to three-quarters (77\%) of Oregon residents age $45+$.

Important Livable Community Features

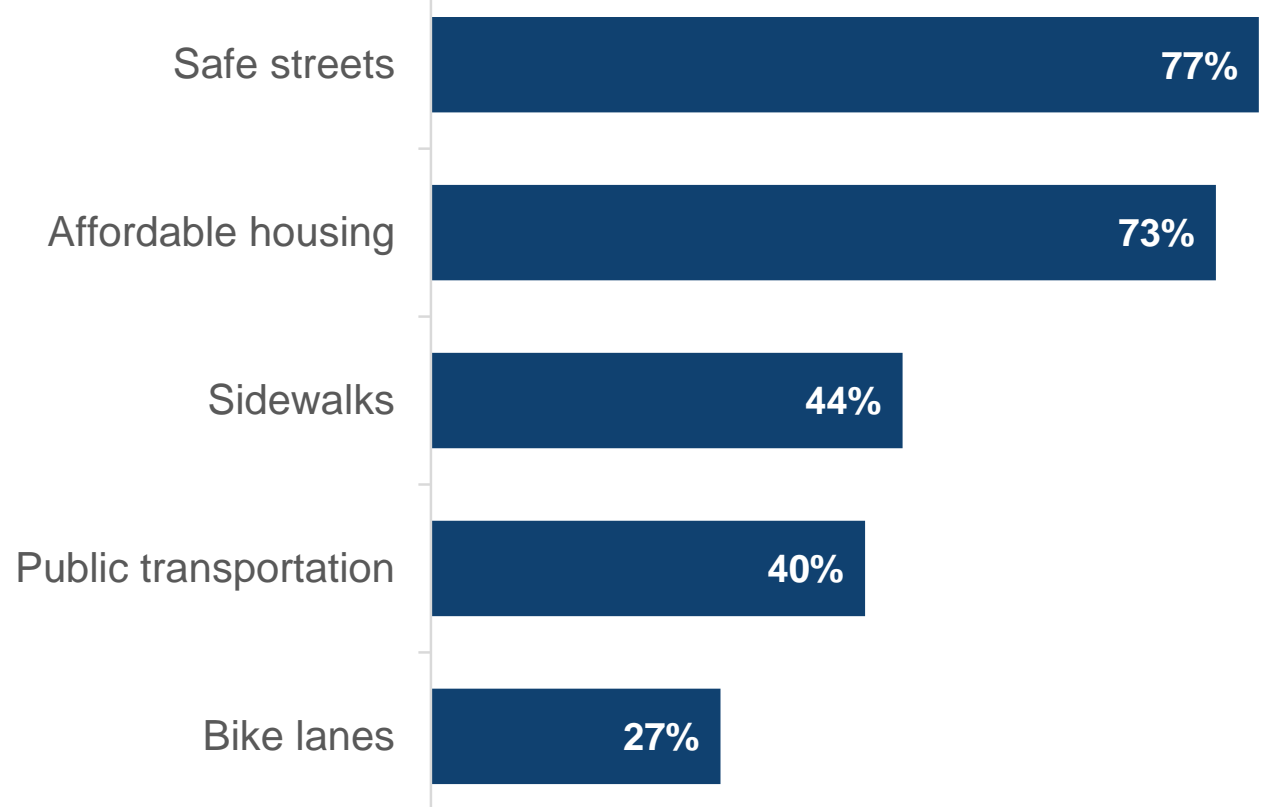

11. For the following list of issues, please indicate how important each is to you personally. (Percent 'extremely important' or 'very important') ( $\mathrm{n}=709)$ 


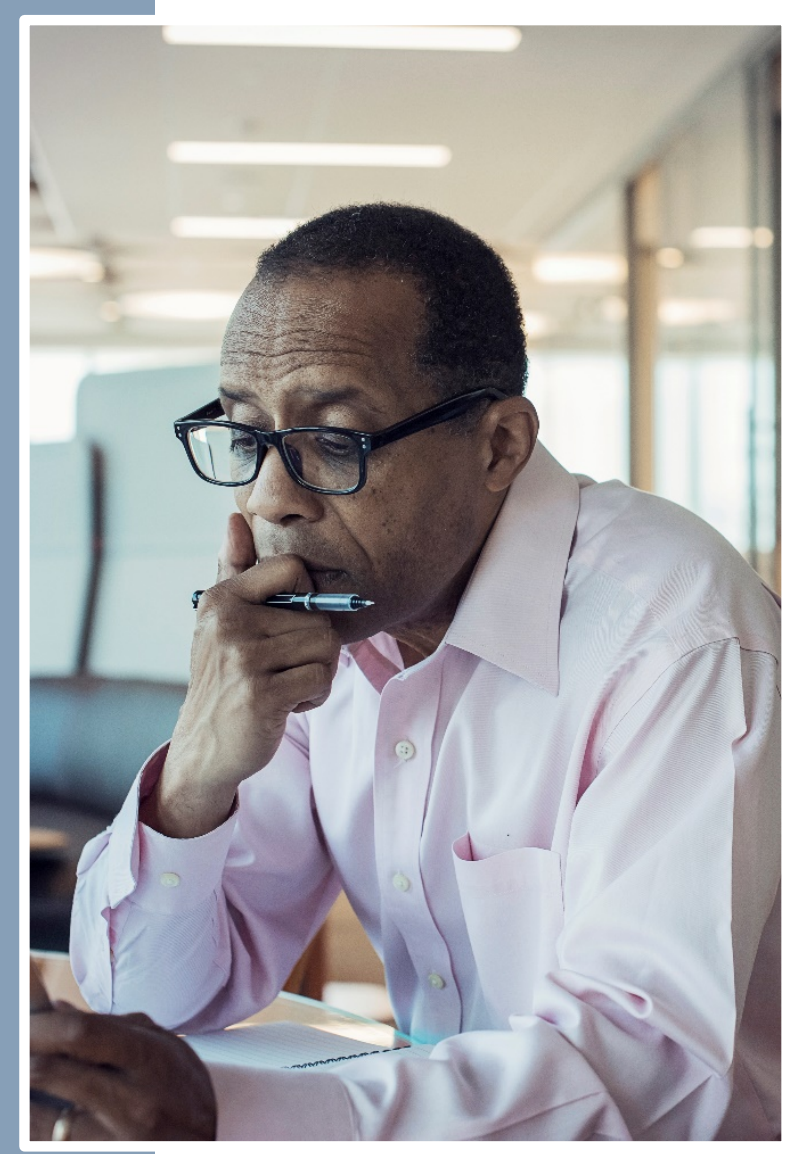

DA1. Based on what you have seen or experienced, do you think older workers face discrimination in the workplace today, based on age? $(n=709)$

\section{DISRUPT AGING}

Two-thirds (66\%) of Oregon residents age $45+$ believe older workers face age discrimination in the workplace today.

Age Discrimination in the Workplace

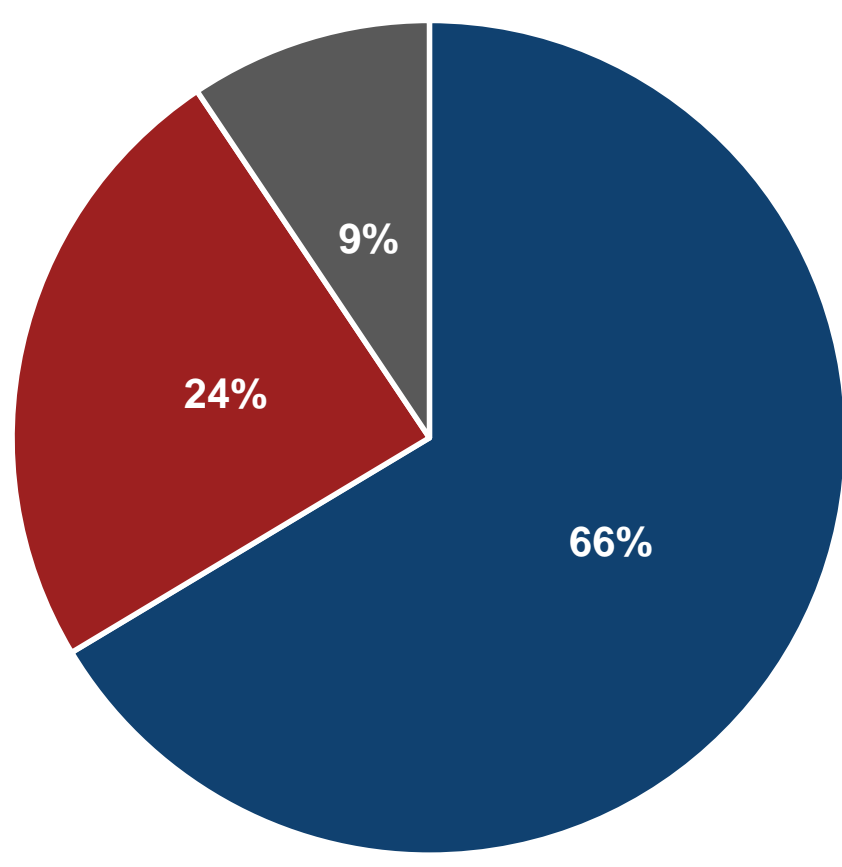

- Yes - No - Don't know/ refused 


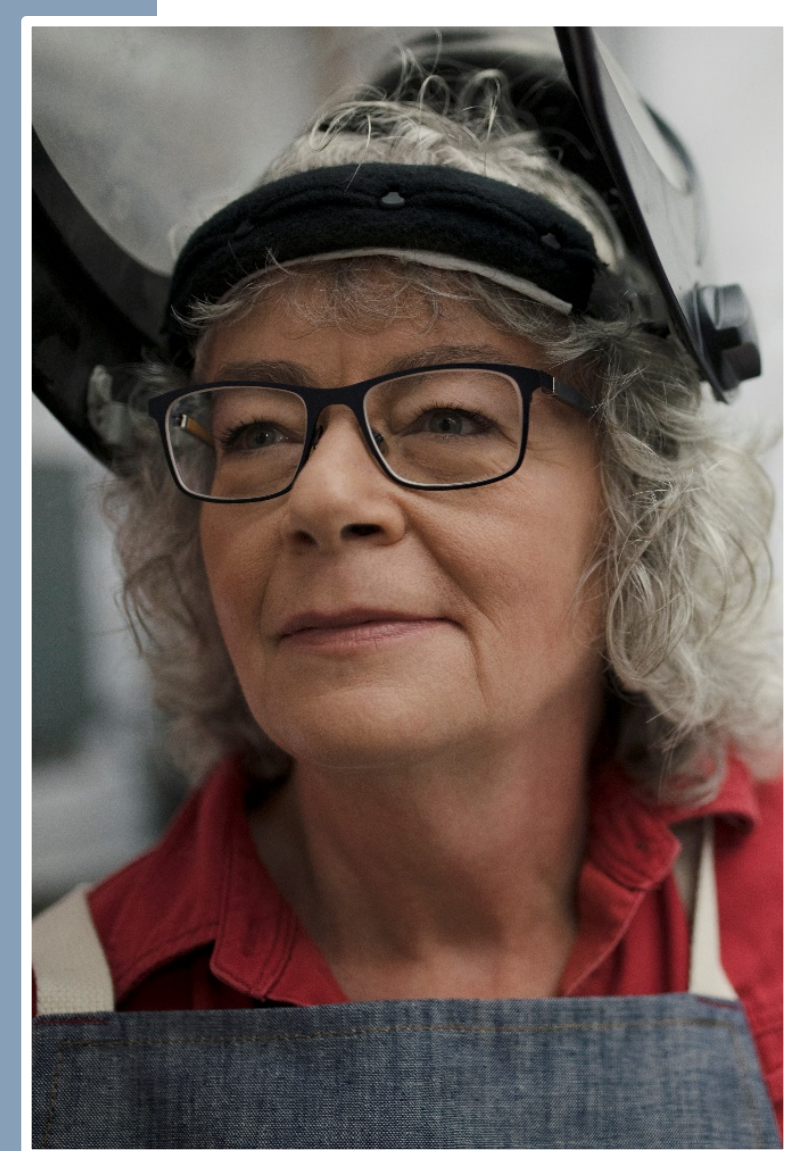

DA3. How common is age discrimination against older workers in the workplace today? $(n=471)$

\section{DISRUPT AGING}

Among Oregon residents age 45+ who believe age discrimination is an issue in the workplace today, half (55\%) feel it is extremely common or very common.

Prevalence of Age Discrimination Against Older Workers

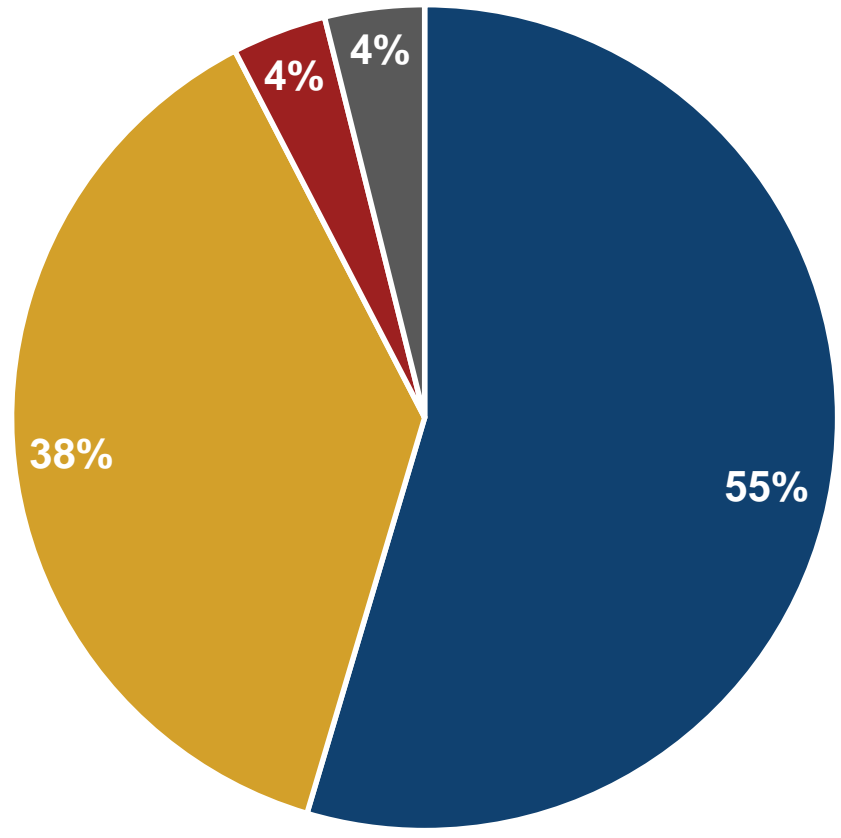

- Extremely common/ very common

- Not very common/ not at all common

- Somewhat common

- Don't know/ refused 


\section{DISRUPT AGING}

One-quarter (26\%) of Oregon residents age $45+$ have heard negative remarks related to old age from a supervisor or colleague since turning 40.

\section{Age Discrimination in the Workplace}

Heard negative remarks related to old age in general from a supervisor or colleague

Not been hired for a job you applied for because of your age

Heard negative remarks related to your older age from a supervisor or colleague

Passed up for a promotion or a chance to get ahead because of your age

Been laid off, fired, or forced out of a job because of your age

Denied access to training or professional development opportunities because of your age 


\section{DISRUPT AGING}

Among Oregon residents age 45+ who think age discrimination is an issue in the workplace today, half (53\%) believe it starts when workers are in their fifties.

When Age Discrimination Begins in the Workplace

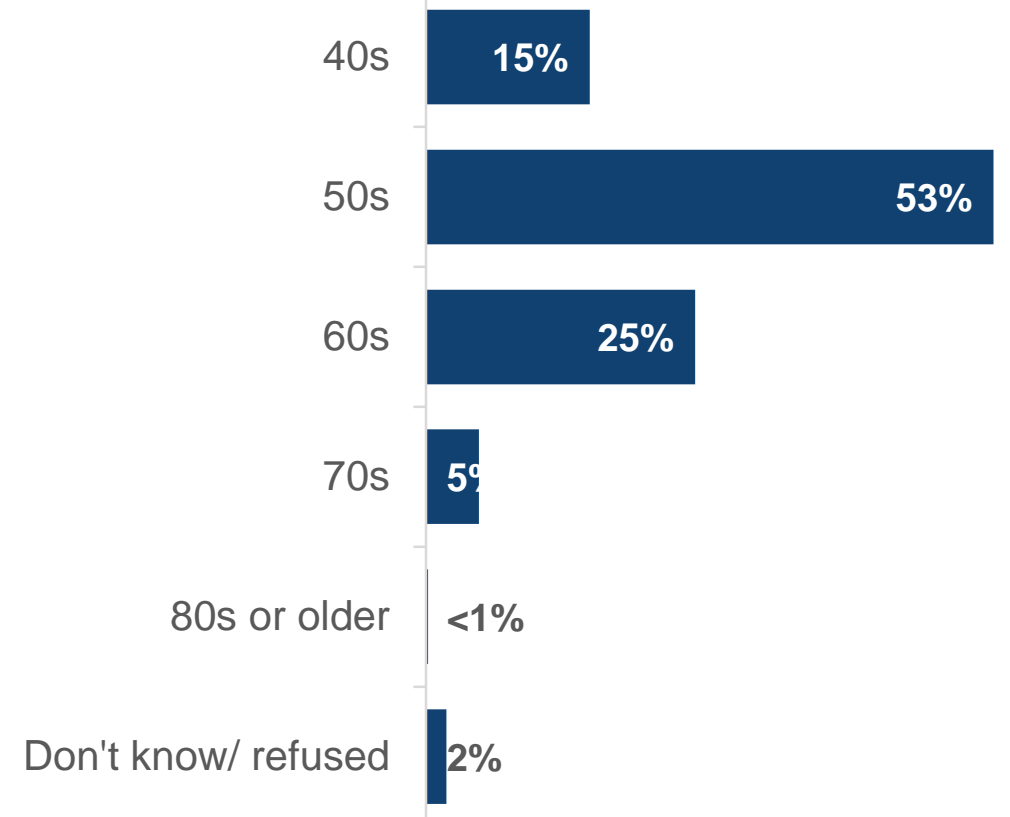

DA2. At what age do you think older workers begin to face age discrimination? $(n=471)$ 


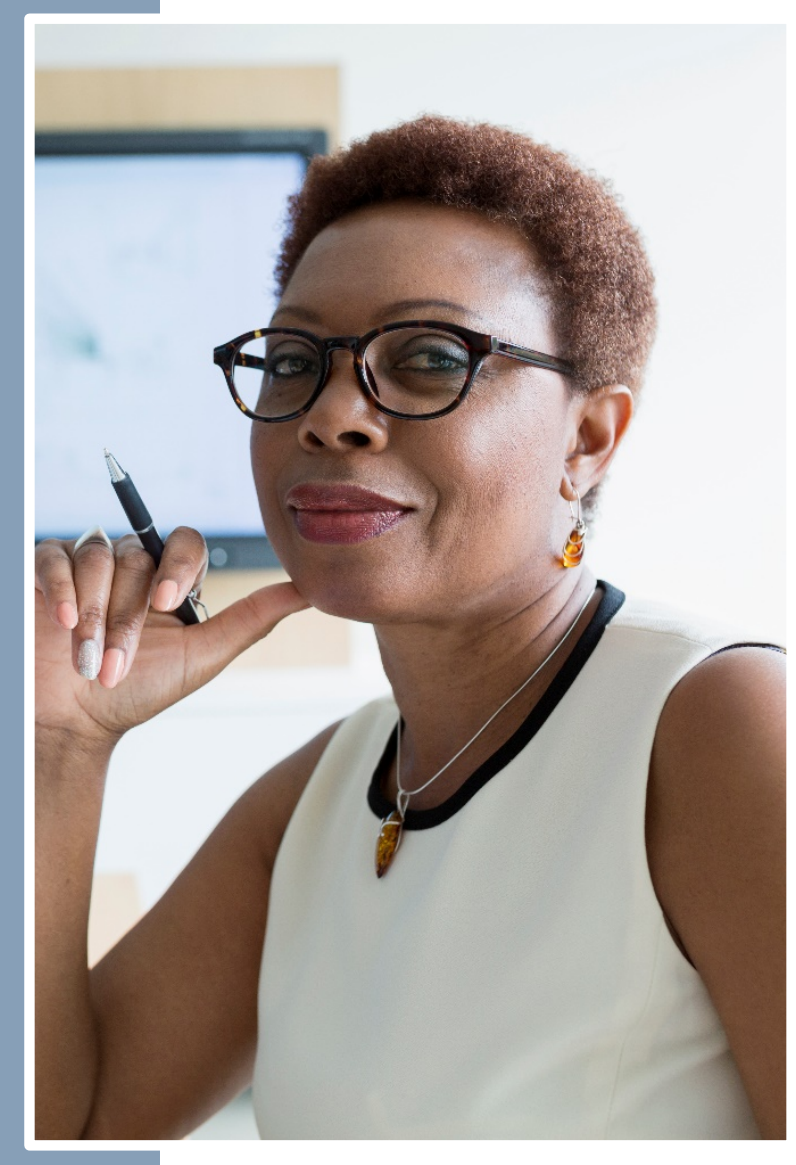

DA5. Have you ever made a complaint to a supervisor

human resources

representative, a government agency, or another organization about age discrimination that you have seen or experienced in the workplace? $(n=471)$

\section{DISRUPT AGING}

Among Oregon residents age 45+ who believe age discrimination is an issue in the workplace today, most (91\%) have not personally filed a complaint.

Made a Complaint About Age Discrimination in the Workplace

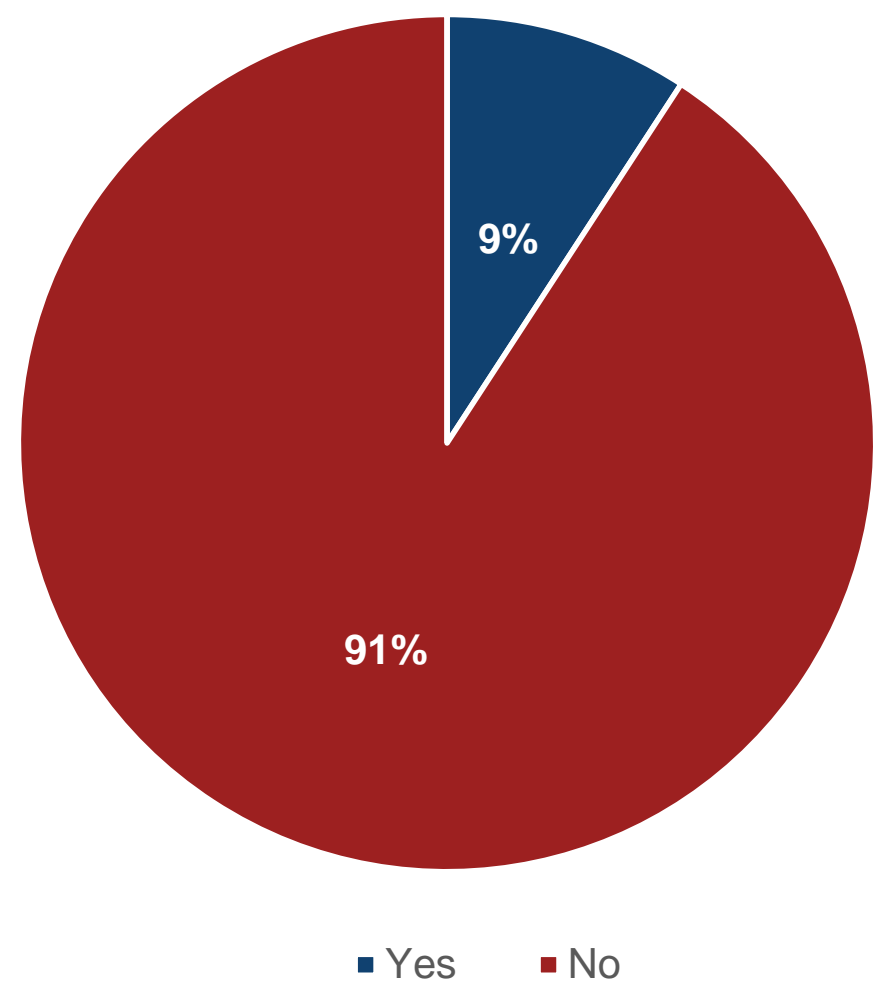




\section{METHODOLOGY}

In November 2020, AARP engaged ANR Market Research Consultants to conduct a quantitative research study among Oregon adults age 45 and older. Topics included healthcare, the economy, financial issues, independent living, long-term care, caregiving, and retirement issues.

\section{Interviews}

\section{Oregon Residents Age 45+}

\section{Fielded in November/December 2020}

ANR completed a total of 709 interviews (358 via landline telephone, 195 via cell phone, and 156 online). Respondents were screened to meet the following criteria:

- Age 45+

- Resident of Oregon

Survey length averaged 21.7 minutes by telephone and 20.2 minutes online.

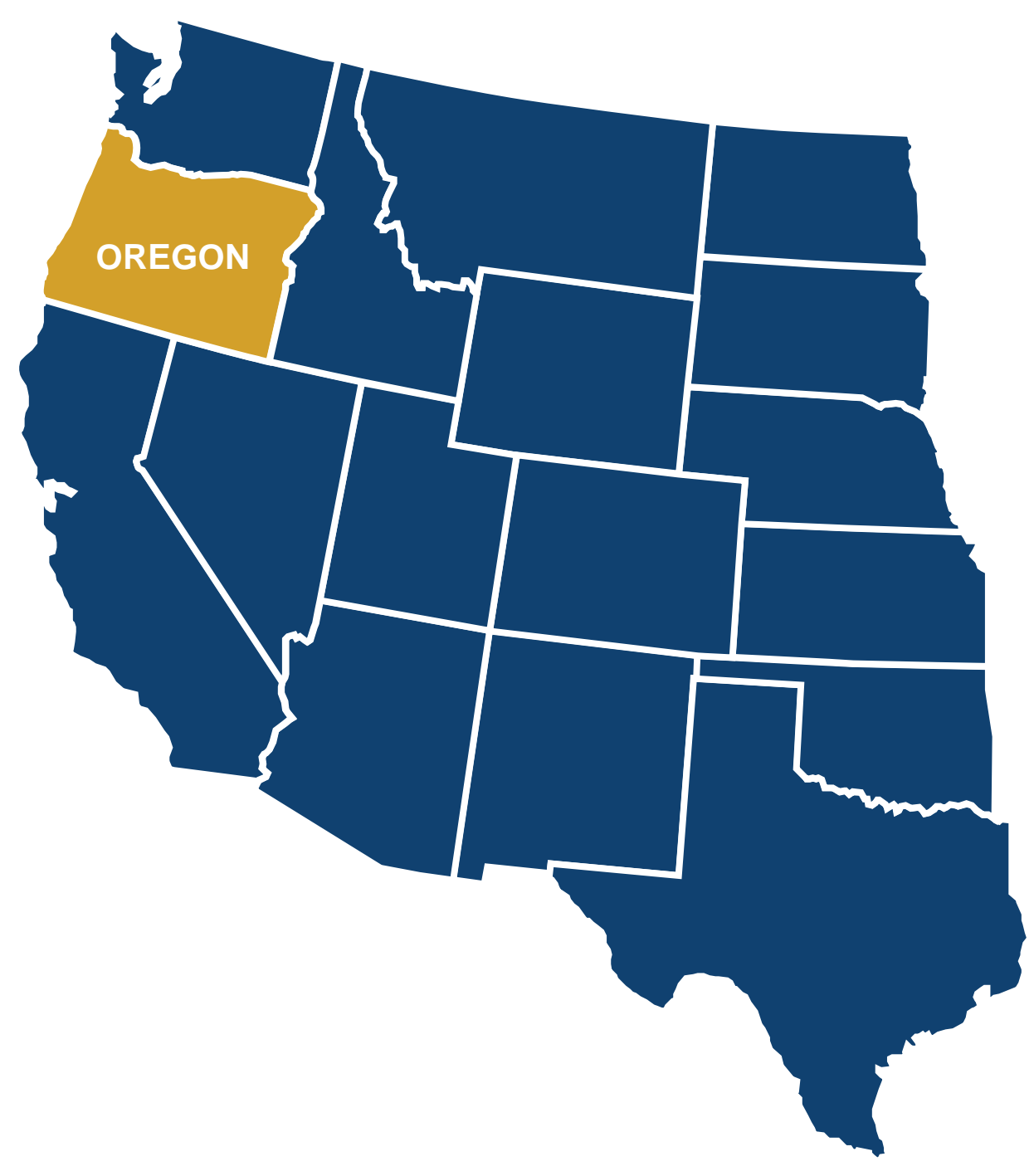




\section{METHODOLOGY}

\section{Sampling Procedure}

Landline, cell phone, and online sampling were used for this research, with the telephone sample drawn randomly from a list of Oregon residents age 45 and older, purchased from Aristotle, and online sample provided by Fulcrum. A total of 40,026 records were utilized. The list of 1,738,000 Oregon residents age 45 and older was randomly divided into 1,738 replicates of 1,000 records for telephone dialing. Initially, 20 replicates were released for calling, with additional replicates being opened as necessary. In all, 41 replicates representing a total of 40,026 records were dialed to complete the telephone portion of this study.

The sample of 709 respondents yields a maximum statistical error of $\pm 3.7 \%$ at the $95 \%$ level of confidence. (This means that in 95 out of 100 samples of this size, the results obtained in the sample would be within \pm 3.7 percentage points of the results obtained had everyone in the population been interviewed.)

\section{Interview Methodology}

The survey was launched on November 28, 2020 and closed on December 6, 2020.

Telephone interviewing was active between 5:30 p.m. and 9:00 p.m., with some additional calling done between 10:00 a.m. and 4:00 p.m. If necessary, up to 8 call attempts per telephone number were made to reach an eligible respondent. All numbers were called at multiple times of the day as well as days of the week to maximize each resident's opportunity for inclusion in the study.

Percentages of some questions may exceed $100 \%$ due to rounding or the use of multiple response question formats.

All data have been weighted by age, gender, and race/ethnicity according to 2018 U.S. Census Bureau Current Population Survey (CPS) statistics

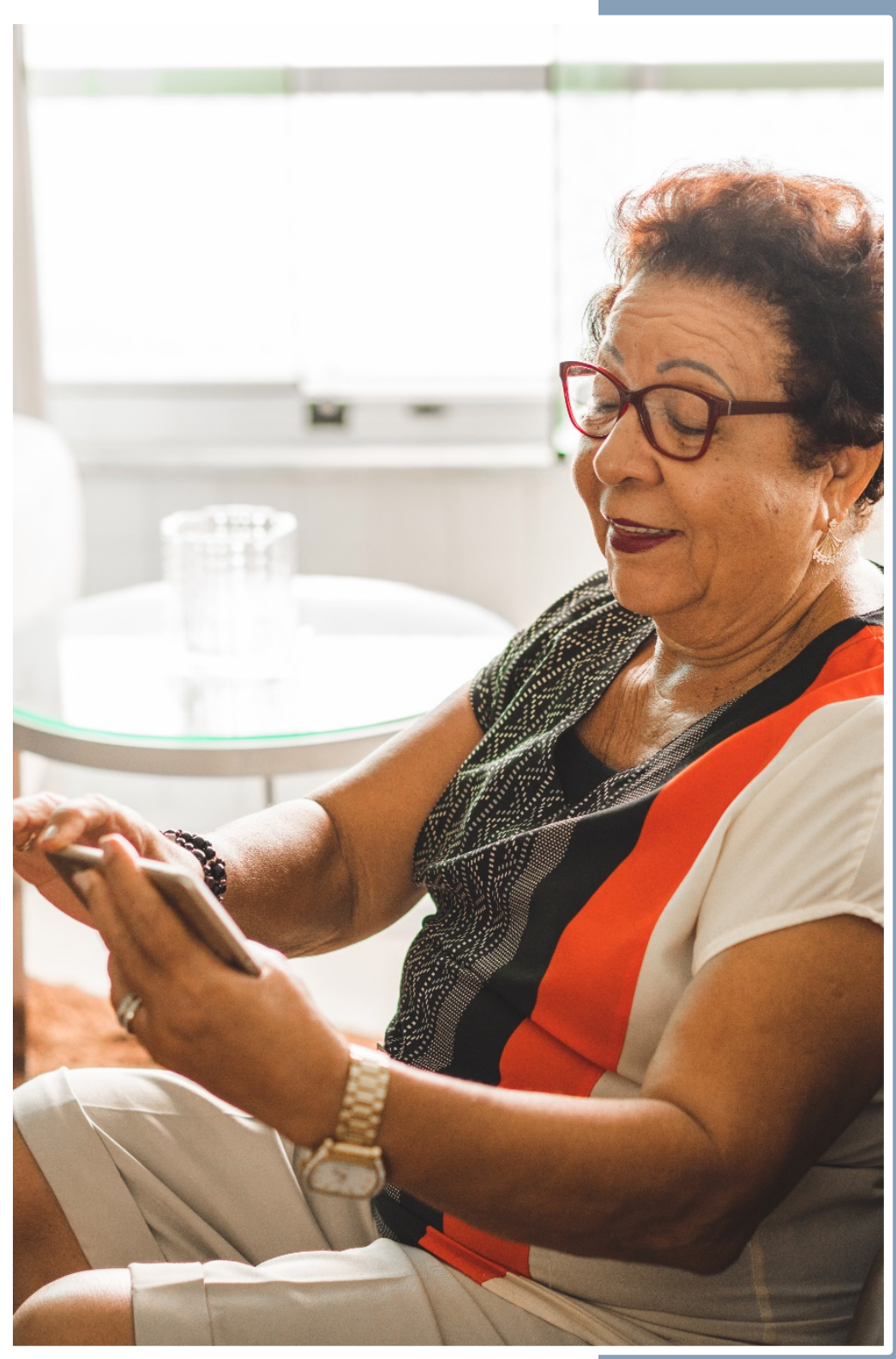




\section{ABOUT AARP}

AARP is the nation's largest nonprofit, nonpartisan organization dedicated to empowering Americans 50 and older to choose how they live as they age. With nearly 38 million members and offices in every state, the District of Columbia, Puerto Rico, and the U.S.

Virgin Islands, AARP works to strengthen communities and advocate for what matters most to families with a focus on health security, financial stability and personal fulfillment. AARP also works for individuals in the marketplace by sparking new solutions and allowing carefully chosen, high-quality products and services to carry the AARP name. As a trusted source for news and information, AARP produces the nation's largest circulation publications, AARP The Magazine and AARP Bulletin. To learn more, visit www.aarp.org or follow @AARP and @AARPadvocates on social media.

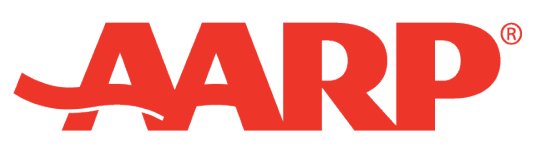

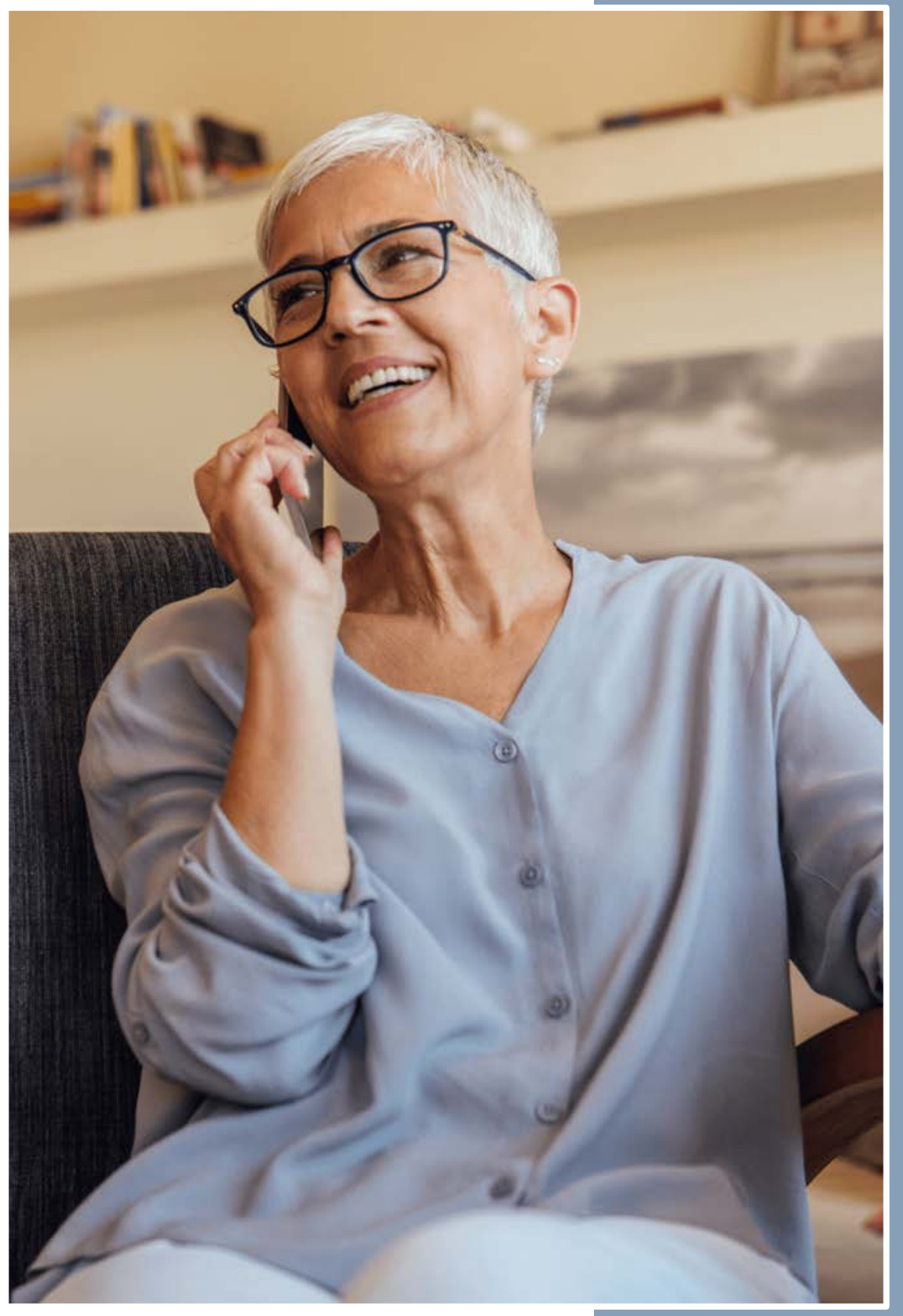

30 


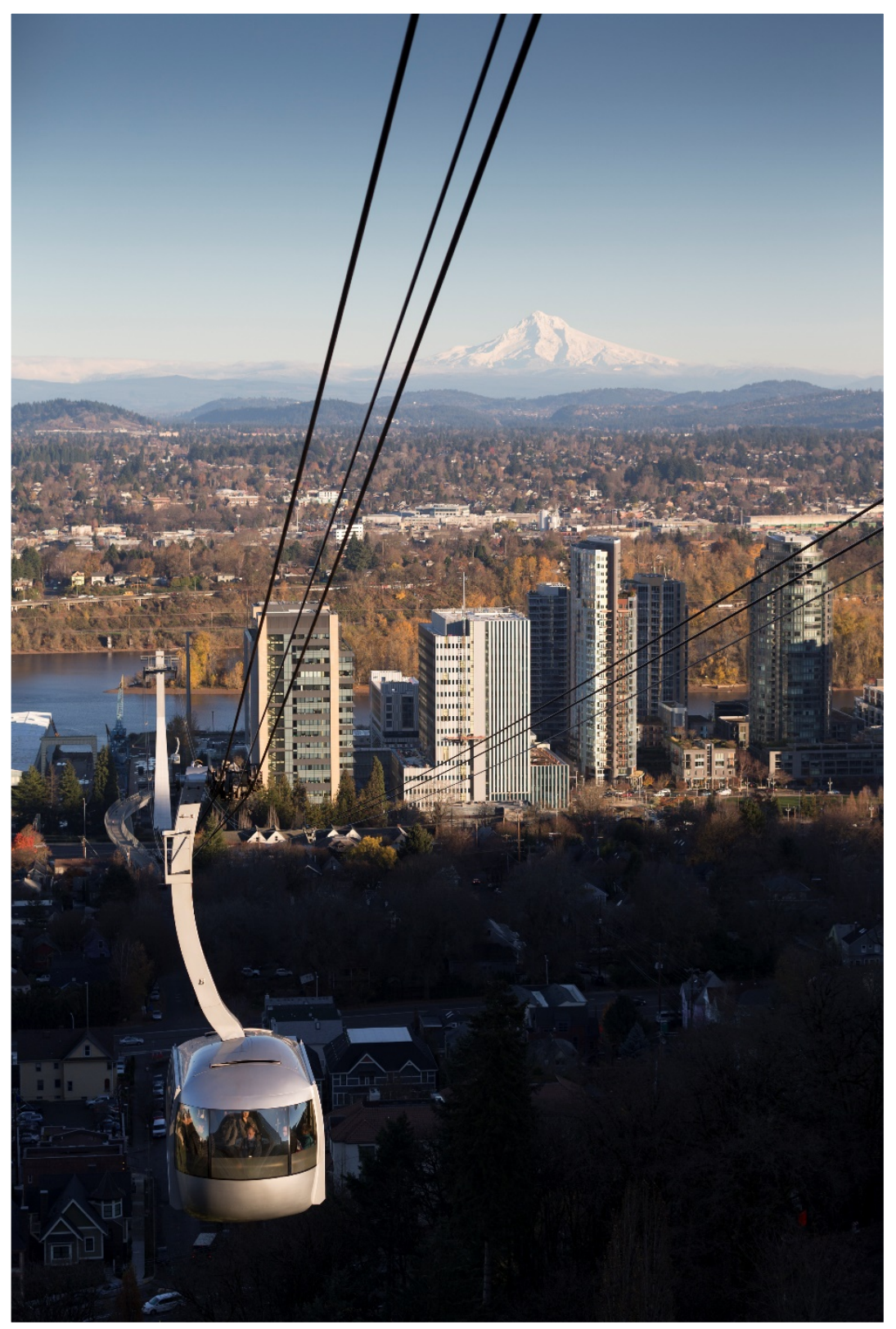

AARP

\section{CONTACT}

Aisha Bonner Cozad,

ABonner@aarp.org

For media inquiries, please

contact media@aarp.org.

This research was designed and executed by AARP Research. 